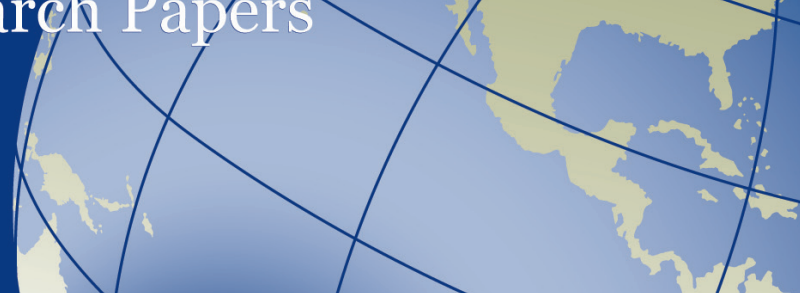

Volume 7 • Issue 12 - May 2014

\title{
ALBERTA CITIES AT THE CROSSROADS: URBAN DEVELOPMENT CHALLENGES AND OPPORTUNITIES IN HISTORICAL AND COMPARATIVE PERSPECTIVE
}

\author{
Zack Taylor, University of Toronto Scarborough \\ Marcy Burchfield, Neptis Foundation \\ Anna Kramer, Neptis Foundation
}

\section{SUMMARY}

Fuelled by the province's booming energy sector, Alberta's two largest cities have experienced unprecedented levels of growth. As a result, they face a choice about how to best accommodate their expanding populations - whether to grow out or grow up. For decades, Calgary and Edmonton accommodated almost all growth through the former, suburban expansion. Indeed, the postwar period was marked by a focus on contiguous outward growth to ensure housing affordability and the efficient use of infrastructure, a policy that was widely supported by both the public and the development industry.

In Calgary, at least, this has started to change. Beginning in the late 1990s, the city shifted its focus to livability and sustainability, a move that saw policies introduced to promote urban intensification and greater transit use. While this shift has proven popular in many quarters, it also has its fair share of detractors, including many in the development industry. In Edmonton, a city where growth has been relatively slower and authority over urban development dispersed among several local governments, this policy shift has not occurred.

Although it is too early to see clear results from this policy shift, a spatial analysis shows that the density of Calgary's built-up urban area increased in the first decade of the 21st century. Relatively high-density suburban growth led Calgary to consume less land compared with the previous decade ( 2 ha per 100 new residents in 2001-2011 versus 6.5 ha in 1991-2001). This growth was accompanied by modest intensification in core areas, although the dwelling unit density of the urban area increased by more than the population density (18 per cent versus 14 per cent). Edmonton's development is roughly similar: denser suburban growth has led to the more efficient consumption of rural land (3 ha per 100 new residents in the 2001-11 period versus 7 ha in 1991-2001). The built-up area has also intensified slightly, especially in areas near transit stations.

By way of comparison, Vancouver with its long-standing urban containment policies, including the expansion limits represented by the Agricultural Land Reserve, grew mostly through intensification between 1991 and 2011. In Toronto, the second comparator city examined and one in which local growth management policies have existed since the 1980s, growth is now almost equally divided between intensification and suburban expansion.

The analysis suggests that it is difficult to alter a deep-seated policy regime that promotes outward growth. What is more, high levels of intensification may not be enough to offset the effects of a new demographic reality: smaller average household size because of such factors as longer lifespans, delayed family formation, family planning and divorce. So even with a greater number of housing units, the population of the built-up area may still fall. Finally, if the emerging polycentric structures of Calgary and Edmonton are to be successfully supported, major investments in infrastructure are going to be required. 


\section{INTRODUCTION ${ }^{l}$}

Alberta's two largest cities are at a crossroads. Fuelled by the province's booming energy sector, Calgary and Edmonton are expanding rapidly. The continuation of this growth hinges on two factors beyond local, or even provincial, control: fickle global demand and transportation constraints on exports. As happened in the early 1980s, the boom may yet be followed by a bust, and the province hit hard by the attendant consequences. In the meantime, however, Alberta is prospering, and its two largest cities are growing. As each city-region's population has surpassed one million during the past decade, the infrastructural costs and ecological limits associated with being a "big city" are making themselves felt. Despite the pressing nature of these challenges, governments at all levels have been reluctant to make major investments in infrastructure.

Citizens, as well as local and provincial policymakers, face important and far-reaching questions: How should cities grow? What role should government play in regulating urban development? How should policymaking and implementation responsibilities be apportioned among different levels of government? Who should pay for infrastructure expansion? In recent years, these are the questions that have dominated Calgary's public agenda as the city has revised its land use and transportation plans. These plans are controversial because they represent a redirection of policy goals for urban development. While in the past the city accommodated virtually all growth through outward suburban expansion, the new policies promote infill and redevelopment in existing urban areas. Such debates have been more muted in Edmonton, where growth has been slower and the authority over urban development dispersed among several local governments and the Capital Region Board. Nonetheless, Edmontonians face broadly similar policy dilemmas.

The goal of this report is not to pronounce on which policy options Calgary and Edmonton should choose, or on what the ideal form of the city should be. Policy choices should be resolved through public debate. Economists, planners and engineers disagree as to the economic, fiscal, social and environmental performance of different urban forms. ${ }^{2}$ This question cannot be comprehensively answered here. Instead, this report places Calgary and Edmonton's contemporary urban development challenges in historical and comparative perspective, revealing how the institutions, principles and practices related to urban development, as well as measurable urban growth patterns, differ. This comparative historical approach also contributes to our understanding of the potential for durable policy change as new urbanization-related problems emerge.

1 Originally presented at the Fourth Symposium in Tax and Economic Growth: Urban Growth and Finance, Walton Consortium Taxation and Economic Growth Program, The School of Public Policy, University of Calgary (October 12, 2013). For more information on methods and sources, please visit the Growing Cities page on the Neptis Foundation website, www.neptis.org. The authors dedicate this work to the late Anthony C. Coombes, founding executive director of the Neptis Foundation, who believed in the necessity of regional planning and commissioned an earlier version of this project. The authors also wish to acknowledge the helpful comments of the anonymous referees.

2 See, for example, Marcial H. Echenique, Anthony J. Hargreaves, Gordon Mitchell, and Anil, Namdeo, "Growing Cities Sustainably," Journal of the American Planning Association 78, no. 2 (2012): 121-37; Reid Ewing and Robert Cervero, "Travel and Built Environment: A Meta-Analysis," Journal of the American Planning Association 76, no. 3 (2010): 265-94; Peter Gordon and Harry W. Richardson, “Are Compact Cities a Desirable Planning Goal?” Journal of the American Planning Association 63, no. 1 (1997): 95-106. 
While the emphasis is on Calgary and Edmonton, we also analyze two other rapidly growing Canadian comparators, Toronto and Vancouver. These regions differ in territorial extent and population size - Edmonton and Calgary straddle the one-million mark, Vancouver is twice as large and Toronto tops six million - yet they have faced similar urbanization-related challenges over the past half century. The lessons learned (or not) in one city's history may be relevant to another city in the present or future (see Figure 1).

This report is in three sections. The first outlines the concepts and methods used in the analysis. The next section discusses Calgary and Edmonton in the context of provincial policy. The final section analyzes Toronto and Vancouver with an eye to what the two Alberta cities can learn from their experiences. For each city, we provide a qualitative policy review - a brief description of major postwar institutional changes and policy decisions that have shaped recent and contemporary urban development patterns - that is related to a quantitative spatial analysis of how urban development patterns have changed over the past two decades. ${ }^{3}$ Following a comparison of urban development policy regimes and growth patterns in all four cities, the report concludes with a discussion of what Calgary and Edmonton can learn from Toronto and Vancouver. Finally, we consider how each city's urban development policy regime might aid or inhibit each city as it confronts contemporary and future problems associated with urbanization.

3 The analysis supplements and extends an earlier study by two of the authors, Zack Taylor and Marcy Burchfield, Growing Cities: Comparing Urban Growth Patterns and Regional Growth Policies in Calgary, Toronto and Vancouver (Toronto: Neptis Foundation, 2010), in which we measured how much growth had occurred within the built-up area and through suburban expansion between 1991 and 2001 in Calgary, Toronto and Vancouver. This report adds Edmonton and updates the findings to 2011. 
FIGURE 1: THE FOUR REGIONS
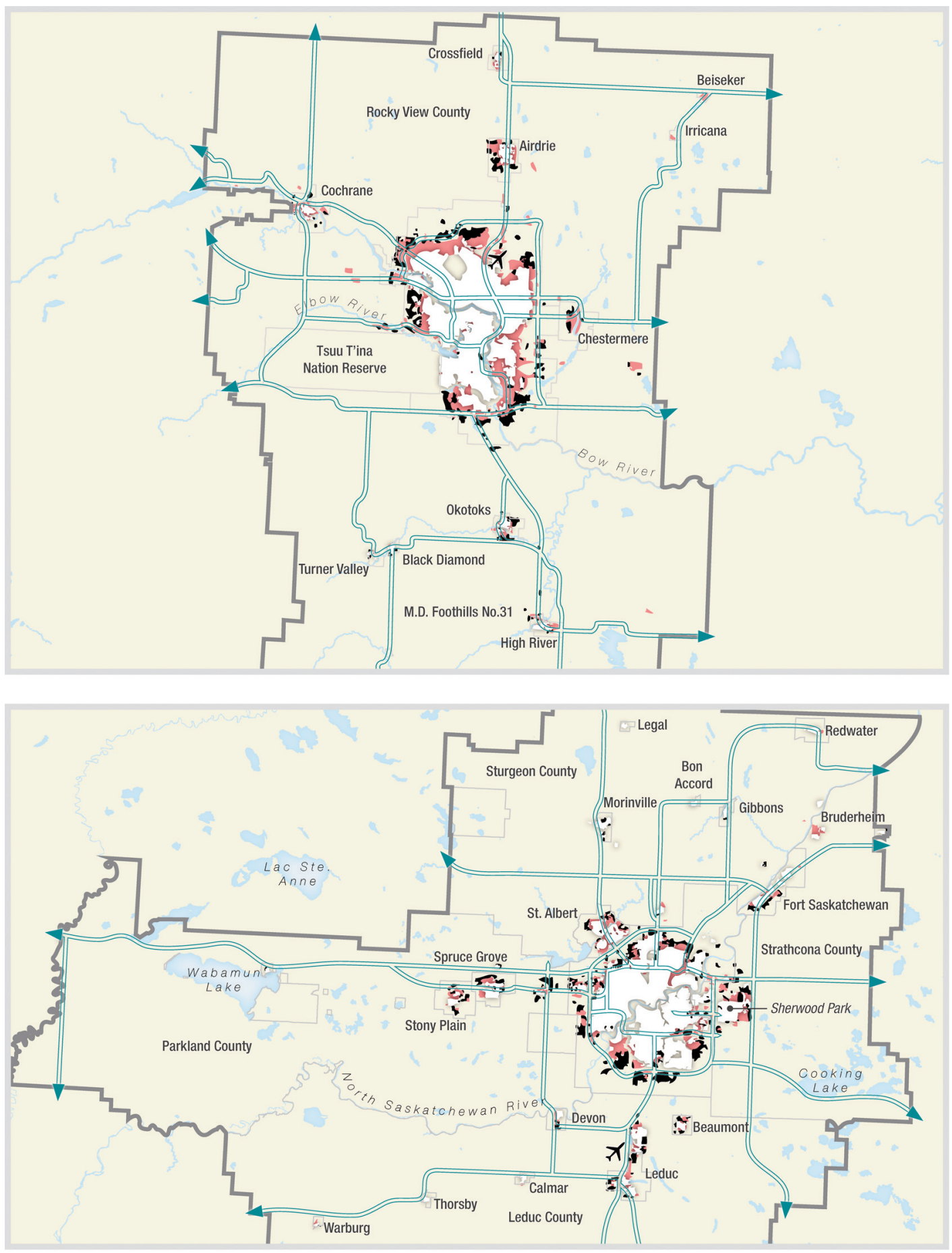

The Calgary region is defined as the City of Calgary plus Rocky View County and Municipal District of Foothills No. 31, as well as their associated municipalities. The Edmonton region is defined as the City of Edmonton plus the counties of Lamont, Leduc, Parkland, Strathcona, Sturgeon and their associated municipalities.

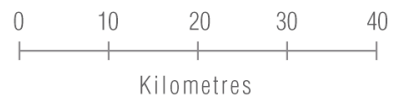



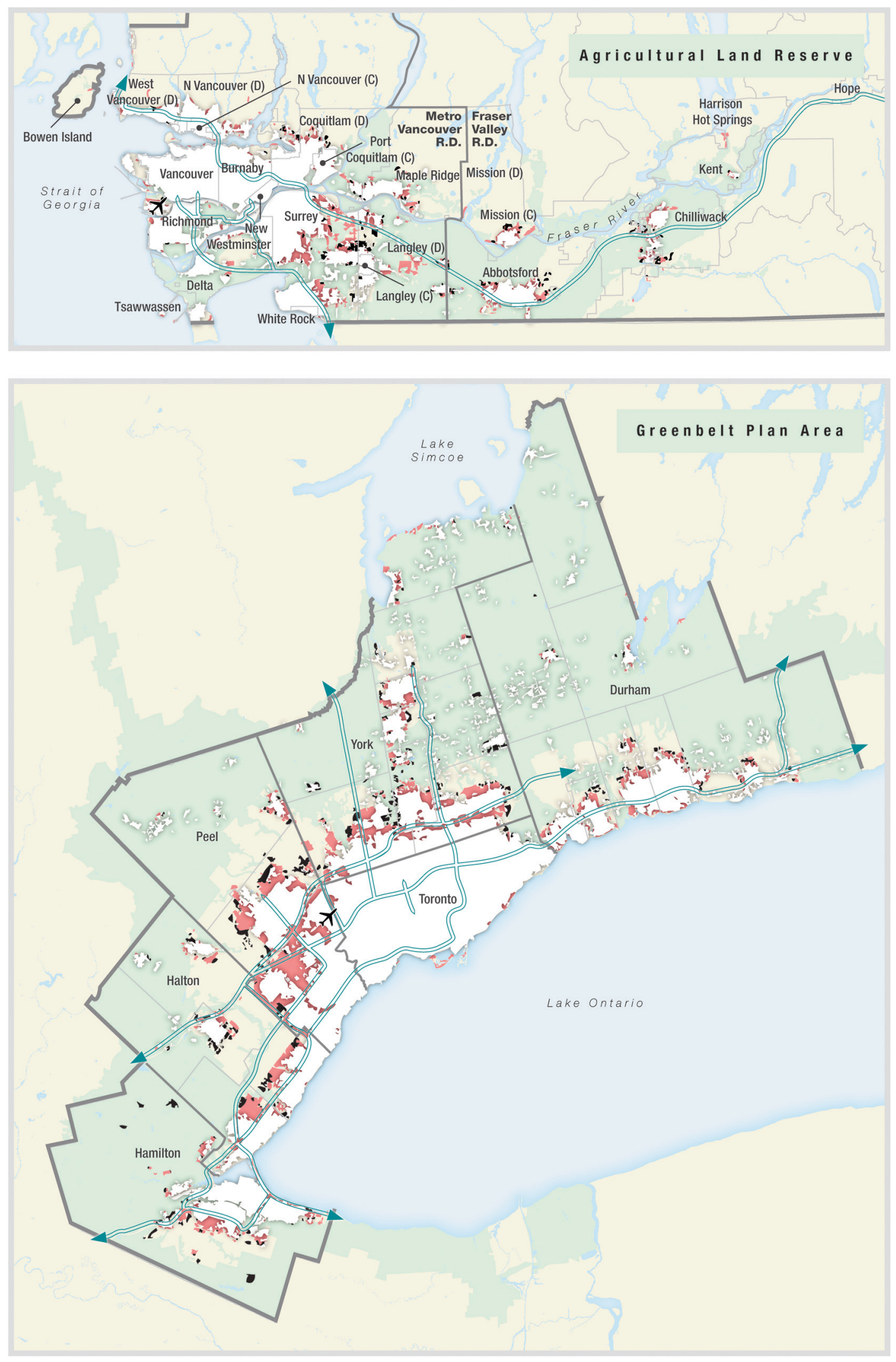

The Vancouver region is defined as Metro Vancouver and the Fraser Valley Regional Districts. (C) indicates a city, while (D) indicates a district municipality. The Toronto Region is defined as the Cities of Toronto and Hamilton plus the regional municipalities of Halton, Peel, York and Durham. Lower-tier municipalities are not labeled. 


\section{CONCEPTS AND METHODS}

\section{The Urban Development Policy Regime Framework ${ }^{4}$}

The policy reviews are structured by Carter A. Wilson's policy regime framework. ${ }^{5}$ A policy regime can be thought of as a durable set of complementary conditions and governing arrangements that support a particular policy direction. Because of these complementarities, a change in one part of the regime can lead to challenge or collapse of the whole, and potentially the establishment of a new policy regime. Often, policy analysis focuses narrowly on the making and implementation of specific policies or the work of a single government institution. The policy regime framework is more encompassing and, therefore, more useful as it enables explanation of stability and change in the broad direction of policy pursued by multiple governments over an extended period of time.

As applied to urban development, the policy regime has four components:

- Institutions: Formal governing institutions organize how policies are made and implemented. Institutional fragmentation may undermine policymaking and implementation. Of particular importance in this comparison is the authority of metropolitan institutions and how they function in relation to provincial-local and intermunicipal relationships. If the policymaker is not the implementer, monitoring and compliance mechanisms are required, potentially at significant fiscal and political cost. If the territorial jurisdiction of the implementing authority is too small, it cannot internalize the region's urban growth.

- Influence: In Canada, urban land markets are dominated by the private sector (i.e., property developers, builders and lenders). Urban development policies that these groups oppose are unlikely to be implemented effectively. These groups tend to resist policy changes that disrupt established practices and impose unanticipated costs. For example, developers and builders may have made substantial speculative investments in land and may have specialized in the financing and production of a particular housing product. Their ability to resist policy change depends on their cohesiveness as an interest group, while their desire to do so depends on their capacity to profitably redirect their activities.

- Policy paradigm: The policy paradigm is the set of broadly held assumptions that inform attitudes toward a policy problem and its resolution. Different policies may emerge if urban development is viewed, for example, as a way to minimize public infrastructure costs or increase housing affordability as opposed to a means of protecting rural land or reducing traffic congestion.

- Policy objectives and instruments: The final component is the policy itself - the specific objectives of the policy regime and the regulations used to implement them. In this study, we distinguish two policy domains defined by the location of urban development. Expansion policies regulate the form of urban development on rural land, while intensification policies regulate infill and redevelopment within the already-urbanized area. The substance of each, and the relative emphasis on one or the other, may differ between city-regions and depend on the dominant policy paradigm and the goals of interest groups.

\footnotetext{
4 The policy reviews are based on a close reading of past and present policy documents and reports and the secondary literature. Citations are kept to a minimum to avoid overburdening the reader. Specific sources and page citations are available on request.

5 Carter A. Wilson, "Policy Regimes and Policy Change," Journal of Public Policy 20, no. 3 (2000): 247-74.
} 
The components of the policy regime, and thus the policy regime as a whole, tend to be pathdependent - that is, stable or durable over the long term because the economic and political costs of disrupting investment patterns, adopting new practices, changing rules and enforcing compliance are high. ${ }^{6}$ Nevertheless, a policy regime may be destabilized and replaced by another when change occurs in one or more of its components. For example, a policy paradigm shift may delegitimize existing institutions and policies, leading influential actors to withdraw their support. Policy regimes may also be destabilized by an external "shock." For example, rising mortgage interest rates may undermine housing affordability, generating demand for smaller-format housing; rising energy costs may spur demand for public transit over the automobile; or a water shortage may encourage conservation and infrastructure efficiency policies.

Although a policy regime may be stable, its results are not necessarily optimal. Policies may produce inefficient or undesirable outcomes over the long term as unpriced incremental costs accumulate or critical thresholds are reached. For example, the creation of a low-density, automobile-dependent residential development pattern may initially disperse traffic. Beyond a certain population size and territorial extent, however, the benefits of dispersal may diminish as congestion-related costs multiply.

\section{Spatial Analysis of Urban Development Patterns}

This policy review is related to a spatial analysis of how the four cities have developed during the 1991-2011 period. ${ }^{7}$ In order to describe change in a city's urban structure and compare change processes in different cities, it is necessary to simplify. As noted above, the comparison of urban development policy regimes and spatial analysis of growth patterns relies on a conceptual distinction between two types of urban development: intensification (infill and redevelopment within the existing built-up urban area) and expansion (the conversion of rural land outside the built-up area to urban uses). To measure growth between 1991 and 2001 and between 2001 and 2011, we first defined the built-up urban area through the analysis of satellite imagery from each year. For each decade, we measured the amount of growth that had occurred inside and outside the built-up area as it existed at the beginning of the decade. For the 1991-2001 period, we measured the amount of population and housing growth that had occurred over the decade within and outside the contiguous built-up area as of 1991. For the 2001-11 period, we measured growth within and outside the 2001 built-up area boundary.

6 See James Mahoney and Kathleen Thelen, “A Theory of Gradual Institutional Change," in Explaining Institutional Change: Ambiguity, Agency, and Power, ed. James Mahoney and Kathleen Thelen (New York: Cambridge University Press, 2010), 1-37; Douglass C. North, Institutions, Institutional Change and Economic Performance (New York: Cambridge, 1990); Paul Pierson, "Increasing Returns, Path Dependence, and the Study of Politics," American Political Science Review 94, no. 2 (2000): 251-67; and Zack Taylor, "Rethinking Planning Culture: A New Institutionalist Approach," Town Planning Review 84, no. 6 (2013): 683-702.

7 With some modifications, the current analysis extends the 1991-2011 analysis in the original Growing Cities report to 2011. We were unable to extend all parts of the analysis. First, the intensification measures for Calgary and Vancouver differ because of the redefinition of the regional study areas to include outlying settlements that are now part of the commutershed. Second, the method for measuring intensification was modified in the 2001-11 analysis because of concerns about the accuracy of the voluntary National Household Survey that replaced the long-form census in 2011 and the limited availability of data at the time of analysis. After comparing the two methods using 2006 census data, the results were found to be similar. The modification of the 2001-11 intensification analysis did, however, allow for the inclusion of additional variables that were not part of the original study. 
We also measured the amount of newly urbanized land, otherwise known as the expansion area, in each decade. Finally, where applicable, we analyzed the location of intensification in relation to transit stations and designated nodes and centres (see Figure 2). Population and housing data are taken from the 2001 and 2006 long- and short-form Census of Population and the 2011 Census, which exclusively used the short-form.

This binary division may seem reductive. ${ }^{8}$ Nevertheless, as this study shows, these distinctions are relevant in Canadian planning practice, and, more importantly, policymakers employ these terms with some consistency. It makes sense, therefore, to use them to frame the comparative analysis. Moreover, applying standard definitions and methods and using consistent data across jurisdictions enabled us to make an "apples-to-apples" comparison without relying on hard-tocompare data supplied by planning agencies.

\section{FIGURE 2: SPATIAL ANALYSIS METRICS BY ZONE}

\begin{tabular}{|l|l|}
\hline ZONE & METRIC \\
\hline Regional & $\begin{array}{l}\text { Change: Absolute and percentage change in population and dwelling units in the } \\
1991-2001 \text { and 2001-11 periods }\end{array}$ \\
\hline Expansion area & $\begin{array}{l}\text { Areal expansion: Absolute and percentage change in urbanized area in the 1991-2001 } \\
\text { and 2001-11 periods }\end{array}$ \\
\hline Built-up urban area & $\begin{array}{l}\text { Spatial distribution of intensification: By dwelling and population in the 1991-2001 } \\
\text { and 2001-11 periods }\end{array}$ \\
\hline $\begin{array}{l}\text { Density: Population and dwelling unit density of the built-up area in 1991, 2001 and } \\
\text { 2011 }\end{array}$ & $\begin{array}{l}\text { Housing stock composition: Absolute and percentage change in housing stock } \\
\text { composition within the built-up area in the 2001-11 period }\end{array}$ \\
\hline $\begin{array}{l}\text { Transit stations and growth areas: Absolute and percentage of regional population and } \\
\text { dwelling unit change in designated growth areas or adjacent to transit stations in the } \\
\text { 1991-2001 and 2001-11 periods }\end{array}$ \\
\hline
\end{tabular}

8 This is not the only approach to conceptualizing regional urban form. Other researchers have categorized territory within urban regions according to the characteristics and behaviours of their residents. For example, Queen's University professor David Gordon's "Canadian Suburbs" project distinguishes between auto suburbs, transit suburbs and exurbs based on journey-to-work data. Similarly, the "Atlas of Suburbanisms" prepared at the University of Waterloo as part of the "Global Suburbanisms" project visualizes suburban zones based on three dimensions: built form and commuting mode, domestic arrangements and socio-economic status. Ultimately, "urban," "suburban," "exurban," "rural" and other terms are culturally embedded, value-laden and relative. The lived experience and meanings of landscapes are qualitative and cannot be reduced to objective characteristics. 


\section{CONTINUITY AND CHANGE IN CALGARY AND EDMONTON}

Calgary and Edmonton have long had separate destinies. While Calgary has evolved as a regional and, later, national business centre, Edmonton has focused more on government services, higher education and oil patch-related processing activities. Their long-term urban development, however, has been subject to common influences: a changing provincial policy context and the boom-bust cycle of natural resource extraction industries. What in the prewar period had been a rural society and economy was transformed by rapid urbanization following the discovery of oil in Leduc in 1947. And, since the 1970s, the cities of Calgary and Edmonton alone have accounted for more than half the provincial population. Urban growth and decline has paralleled booms and busts in the oil economy. ${ }^{9}$

\section{The Evolution of Provincial Urban Development Policy}

The cities' relative importance within Alberta, combined with the velocity and abruptness of economic booms and busts, has at times forced urban development onto the provincial policy agenda. Since the Second World War, the provincial government has shaped planning and governance in the two cites through legislation, regulation, funding and political persuasion. Provincial action can be divided into two eras. In the first, from 1950 to about 1995, the province encouraged the cities to annex adjacent urbanizing areas while supporting the work of authoritative regional planning bodies. In the current era, the province has encouraged intermunicipal planning (voluntary in Calgary, compulsory in Edmonton) within emerging provincial-level regional planning frameworks. Each of these eras is discussed in turn.

\section{SUPPORTING ANNEXATION AND REGIONAL PLANNING COMMISSIONS, 1950-95}

From their founding at the end of the 19th century until after the Second World War, Edmonton and Calgary incrementally annexed urbanizing fringe areas. This pattern was challenged in Edmonton in the 1950s when rural Strathcona County proposed to build a new freestanding town called Sherwood Park on the city's eastern flank. The Edmonton district planning commission and the City of Edmonton opposed the plan, arguing that accommodating growth within city limits ensured efficient servicing of new urban areas. Sherwood Park was built, but the debate precipitated the province's appointment of the Royal Commission on the Metropolitan Development of Calgary and Edmonton (the McNally Commission). In 1956, the commission recommended an official policy, later known as the UniCity principle, of incremental annexation by the central cities.

Because of general adherence to the UniCity policy since 1956, the vast majority of the population in the Calgary and Edmonton metropolitan areas today is governed by a single public authority (see Figure 3). The two municipal governments supported annexation because it enabled them to internalize the fiscal benefits of suburbanization. Developers and builders

9 Byron Miller, and Alan Smart, “'Heart of the New West'? Oil and Gas, Rapid Growth, and Consequences for Calgary," in Canadian Urban Regions: Trajectories of Growth and Change, ed. Larry S. Bourne, Tom Hutton, Richard G. Shearmur, and Jim Simmons (Toronto: Oxford, 2011), 269-70. 
supported the policy because it secured their investments in land. Over time, peri-urban land was annexed, developed, and provided with urban services to the profit of developers. This dynamic was reinforced during the 1960s as the developer-builder industry consolidated into a few large players with extensive peri-urban landholdings. Annexation has since become controversial in Edmonton because of the proximity of free-standing towns such as St. Albert and Fort Saskatchewan and the growth ambitions of neighbouring jurisdictions, principally Strathcona County. Edmonton's last major annexation took place in 1982 following 15 years of acrimonious debate. As a result, its share of the regional population has steadily decreased. As the Calgary region grows, the City of Calgary's position in its region is becoming more like Edmonton's - a dominant player surrounded by expanding secondary centres. The regional population outside the City of Calgary has almost tripled since 1991, from 67,000 to 180,000. (The population beyond Edmonton's city limits increased by 126,000, or 56 per cent, over the same period.)

A second provincially supported mechanism for managing urban development was the district (later regional) planning commissions (RPCs). ${ }^{10}$ Established in the late 1940s and early 1950s, these were initially hybrid provincial-local bodies whose members were appointed by area municipalities and various provincial ministries and agencies. After 1963, the boards were made up entirely of delegates from municipal councils. The RPCs performed three tasks during the 1950s and 1960s. First, they conducted research on problems related to urbanization and conservation. Second, they provided advisory planning services to rural and small municipalities that lacked planners of their own, including preparing official plans and conducting planning studies. Third, and perhaps most important, the province delegated subdivision approval authority for areas outside Calgary and Edmonton to the RPCs in 1953. Dominance of the RPCs therefore gave Calgary and Edmonton indirect control over the pattern of urban development beyond their boundaries. The goal was simple: to facilitate efficient servicing when annexation occurred, ensuring that fringe-area semi-rural construction outside city limits met "urban" standards.

After 1957, the RPCs were required to prepare general regional plans that identified areas for urban expansion and options for annexation that ensured the economical servicing of water and sewer systems, the avoidance of watercourse pollution and the preservation of natural resources. While "preliminary" plans were quickly adopted, detailed plans remained out of reach owing to the commissions' meager resources. In 1971, a planning fund financed by contributions from the municipalities was established. The Provincial Planning Fund dramatically expanded the RPCs' budgets and activities and, coupled with new planning legislation introduced in 1977 requiring municipal plans to conform to regional plans, spurred the Calgary and Edmonton RPCs to develop more detailed and directive official plans.

\footnotetext{
10 On the creation, work and politics of the RPCs, see Edmonton Metropolitan Regional Planning Commission, $A$ History of Regional and Metropolitan Planning (Edmonton, 1984); Thomas L. Burton, The Roles and Relevance of Alberta's Regional Planning Commissions (Edmonton: Dept. of Recreation Administration, University of Alberta, 1981); David J. Climenhaga, The Death and Life of Regional Planning in the Calgary Area (Ottawa: School of Journalism and Communications, Carleton University, 1997); J. Barry Cullingworth, Urban and Regional Planning in Canada (Oxford: Transaction Press, 1987), 340-47; Lynne Dale and Thomas L. Burton, "Regional Planning in Alberta: Performance and Prospects," Alberta Journal of Planning Practice 3 (1984): 17-41; and Jack Masson and Edward LeSage, Alberta's Local Governments: Politics and Democracy (Edmonton: University of Alberta Press, 1994), 412-22.
} 


\section{FIGURE 3: ANNEXATION AND POPULATION GROWTH IN CALGARY AND EDMMONTON}

(a) Incremental annexation in Calgary and Edmonton

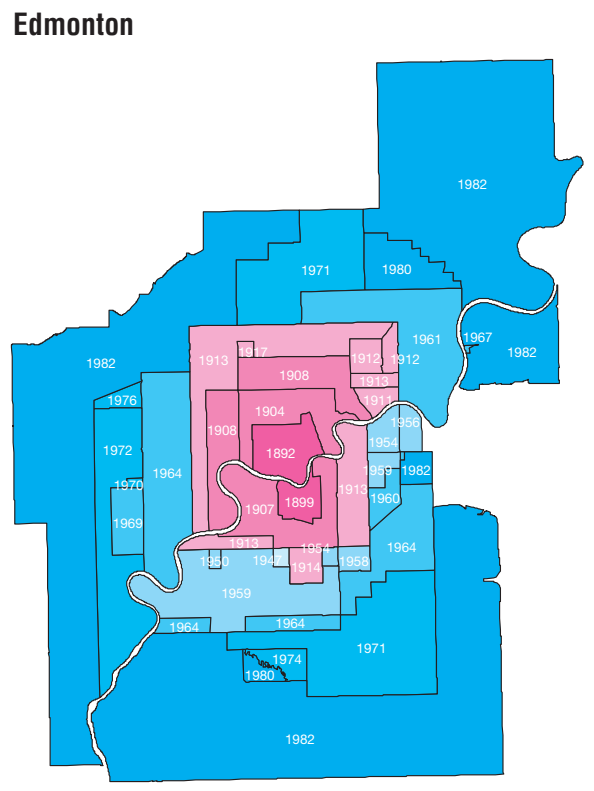

\section{Decade}

\section{onate

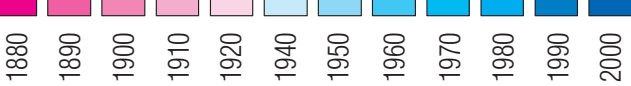

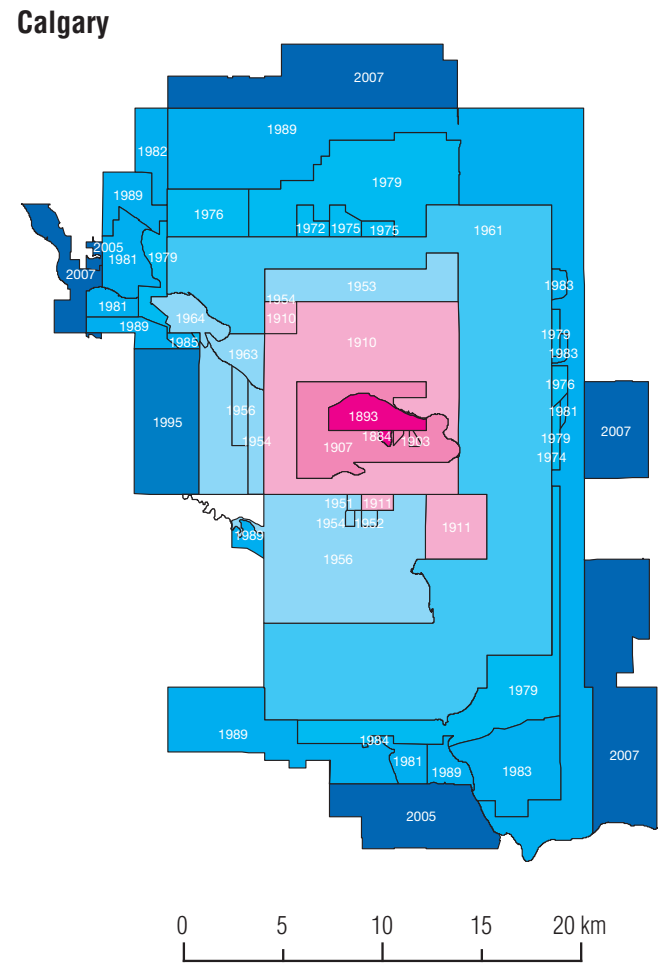

(b) Central city growth and shares of regional population growth, 1951-2011

\section{Municipal population}

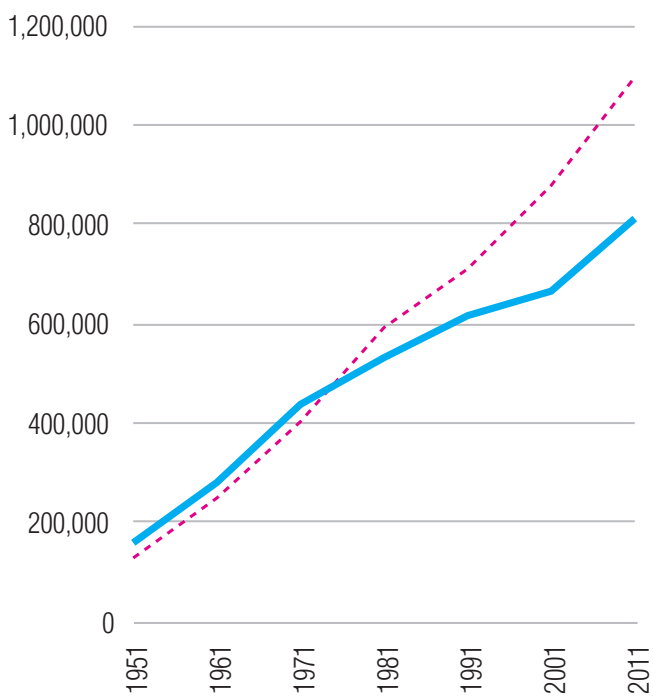

City as \% of Regional Population

$100 \%$
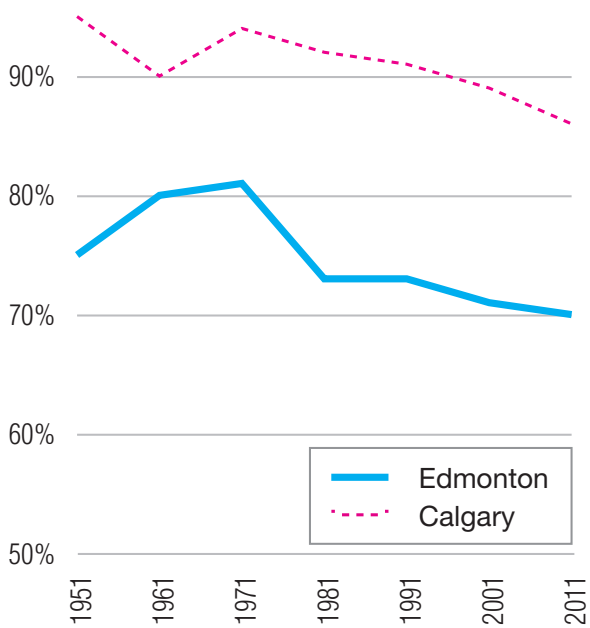
Although the system was effective, its prescriptiveness produced friction between the RPCs and rural municipalities. Although (and perhaps because) the RPCs' planning authority and technical capacity had matured during the 1980s, political support for them was on the wane. On becoming premier in 1993, Ralph Klein abolished the Provincial Planning Fund. Deprived of resources, the regional planning commissions folded. Observers credit the policy shift to electoral politics: the rural areas that formed the bedrock of Conservative support viewed the enforcement of contiguous urban development in tandem with incremental annexation by Calgary and Edmonton RPCs not only as a threat to cherished local autonomy, but also as a deliberate transfer of the fiscal benefits of land development from rural to urban areas.

The revised Municipal Government Act of 1995 formally abolished adopted regional plans and the RPCs, replacing them with voluntary mechanisms of intermunicipal cooperation. This system remains in place today. Municipalities have a duty to consult their neighbours when preparing plans, and two or more municipalities may prepare joint "intermunicipal development plans" for border areas. While not as effective as compulsory planning by RPCs, intermunicipal planning has fostered dialogue between often-antagonistic neighbours. At the same time, the province borrowed provisions from Ontario's Planning Act, which authorize the minister of municipal affairs to issue policy statements with which municipal plans and undertakings must "be consistent." These Land Use Policies require that land use patterns be efficient, orderly and sustainable, and that municipalities "provide intensification opportunities within developed areas where existing infrastructure and facilities have adequate capacity." 11 The Act, however, provides no mechanism for the province to assess, let alone enforce, municipal compliance, so the degree to which the policies influence local planning is not known.

In 2005, the provincial government signaled its intention to become more involved in managing urban and rural land. Following extensive consultation, the government released a non-statutory Land-Use Framework in December 2008. In this document, the province stated its intention to enact regional plans for seven large watershed-based regions. The enabling legislation to make these plans binding on municipalities, the Alberta Land Stewardship Act, was passed in 2009, with the first plan, for the Lower Athabasca region centred on Fort McMurray, coming into effect in 2012. Plan development is under way in the other six regions. What impact this will have on planning for the Calgary and Edmonton metropolitan areas is not yet known, although the government states that its plans for the South Saskatchewan and North Saskatchewan regions (in which each city is located) will align with the intermunicipal planning efforts.

11 Municipal Government Act, section $8.0(1,3)$. 


\section{Calgary}

The City of Calgary dominates its region. ${ }^{12}$ No other urban municipalities are contiguous to it, so its ability to annex territory is virtually unimpeded (see Figure 1). As a result, relationships between municipalities have been less important to shaping urban development than Calgary's municipal policies, although this balance may be changing as growth in satellite communities such as Airdrie, Cochrane and Okotoks accelerates.

Calgary has had a robust system of local and regional planning since the end of the Second World War. The city established a professionally staffed planning department in 1950 - a remarkable step for a municipality of only 129,000 people - and the 1963 Calgary General Plan was the first statutory municipal plan in western Canada. Since then, Calgary has comprehensively revised its general plan four times: in 1970 (updated in 1973), 1979, 1998 and 2009.

At the regional level, the Calgary RPC adopted three plans during its 45-year lifespan. The third and final regional plan, ratified in 1984, built on earlier preliminary or draft plans prepared in 1962 and 1971. The Calgary Regional Partnership, a voluntary consensus-based body formed by area municipalities in 1999, adopted a Calgary Metropolitan Plan in 2012 after five years of consultation and study, although the rural municipal districts surrounding Calgary - Rocky View, Foothills and Wheatland - have either left or refused to join the organization in opposition to Calgary's domination of the body. Despite having earlier endorsed the plan, High River voted to leave the partnership in April 2013. The province has signalled that it will not compel municipalities to participate in the partnership or be bound by the plan.

\section{URBAN EXPANSION POLICIES}

Calgary's local and regional plans have always been intended to facilitate contiguous and fully serviced suburban growth. The primary objective has been to meet housing demand while preserving housing affordability and maximizing infrastructure efficiency. Until the 1970s, there was little question that outward expansion, as opposed to intensification, was the most desirable, if not an inevitable, form of growth, and that this expansion would take the form of low-density tracts of single detached houses. In close cooperation with developer-builders, the city pursued incremental annexation to ensure that new subdivisions were comprehensively planned and fully serviced prior to development. To minimize scattered, unserviceable or premature subdivision of rural land, the city worked through the RPC (when it existed) to channel development in rural areas to locations contiguous to existing urban areas.

\footnotetext{
12 For overviews of postwar municipal and regional planning in Calgary and in Alberta more generally, see Climenhaga, The Death and Life of Regional Planning; Max Foran, Expansive Discourses: Urban Sprawl in Calgary, 1945-1978 (Edmonton: Athabasca University Press, 2009); Michael Gordon and J. David Hulchanski, The Evolution of the Land Use Planning Process in Alberta, 1945-1984, Research Paper No. 156 (Toronto: University of Toronto, Centre for Urban and Community Studies, 1985); and Beverly A. Sandalack and Andrei Nicolai, The Calgary Project: Urban Form / Urban Life (Calgary: University of Calgary Press, 2006).
} 
Since the 1990s, Calgary's official plans have called for denser and more mixed suburban development in order to reduce air pollution, lower infrastructure and servicing costs and better meet community social needs through more mixed-use development. While the 1998 plan contained general policy statements, the 2009 plan requires Area Structure Plans (ASPs) for new suburban areas to surpass a minimum target density of 60 people plus jobs per gross developable hectare and to "demonstrate how a target density of 70 people plus jobs per gross developable hectare can be achieved over the life of the plan." Densification is expected to produce significant cost savings: $\$ 11.2$ billion in infrastructure capital costs and $\$ 130$ million in annual operating costs over the life of the plan. ${ }^{13}$ The plan also requires ASPs to "consider" land use diversity, transit accessibility, active transportation natural features, and access to retail and other amenities in the design of new suburban communities. These features, which are paralleled in the 2012 Calgary Metropolitan Plan, ${ }^{14}$ are analogous to the "complete communities" policies in the most recent Vancouver and Toronto regional plans.

While municipal and provincial plans call for the protection of intraurban natural features such as river valleys and the avoidance of development on, or near, natural resources such as mineral aggregate deposits and sour gas wells, there has been no move to comprehensively protect peri-urban rural land, either for its own sake or as a means of urban containment. However, Intermunicipal Development Plans jointly adopted by the City of Calgary and its neighbours, the Municipal District of Foothills (1996) and Rocky View County (2012), contain policies to limit premature subdivision on active farmland and discourage large-lot "country residential" development outside authorized areas.

A major bone of contention between Calgary and its neighbours is the city's policy, affirmed in 2005 and reflected in the 2012 Calgary Regional Partnership Plan, of refusing to extend trunk water pipes to settlements outside its corporate boundaries if they are not planned at urban densities or contiguous to existing settlements. The goal of this policy was to halt the proliferation of scattered, low-density country residential developments west of the city that are expensive to service. Long-term demand for water is projected to outstrip supply in Calgary's periphery, even if conservation measures prove effective, and most of the region's municipalities are near the limits of their water allocations under the provincial licensing regime (the province stopped issuing new licences in 2006). Calgary's allocation is, however, sufficient to support a population of three million people. While most of the smaller urban municipalities have accepted these conditions, rural municipalities see them as frustrating the legitimate desires of their present and future residents, and they consequently have boycotted the Calgary Regional Partnership and its plan.

\section{INTENSIFICATION POLICIES}

Calgary's historical emphasis on suburban expansion has paralleled a relative lack of interest in the general or targeted intensification of existing urban areas. Given the city's relatively small population size, the ready availability of land for suburban development through annexation and the lack of policy or physical constraints on urban expansion, this attitude is not unexpected.

\footnotetext{
13 City of Calgary, Calgary Municipal Development Plan (Calgary, 2009), section 3.6.2(c).

14 Ibid., section 3.a.
} 
The 1970 and 1979 plans sought to avoid the hollowing out of the downtown and to rehabilitate areas perceived as blighted, but the prevailing distribution of future growth was unchallenged. This direction was maintained in the 1998 plan, and the 1995 Calgary Transportation Plan forecast that 99 per cent of additional city residents between 1991 and 2024 - all but 7,000 of 542,000 - would be accommodated through suburban expansion rather than through intensification.

Adopted following a multi-year "imagineCALGARY" civic engagement process, the 2009 Municipal Development Plan represents a profound shift in policy objectives. The plan calls for 50 per cent of population growth over the next 60 to 70 years to occur through intensification, with an interim target of 33 per cent by 2039. Doing so would obviate the need for future annexation, as all forecast growth could be accommodated within today's municipal boundaries. Similarly, the 2012 Calgary Metropolitan Plan calls for member municipalities to accommodate 25 per cent of new population growth through intensification.

Since the 1970s, Calgary's plans have sought to channel modest growth to the downtown core and Line Rail Transit (LRT) corridors and station areas as a means of promoting transit ridership. (The first phase of the two-line CTrain LRT system became operational in 1981). The 1998 and 2009 plans call for concentrating employment uses into transit-connected "centres" to improve transit use and jobs-housing balance, and the latter plan sets density targets for different classes of centres. The downtown core and designated centres are expected to absorb 40 per cent of forecast population intensification to 2076, with a further 19 per cent to be absorbed by designated corridors. In total, this represents 364,000 people, or 30 per cent of anticipated future growth in the region.

\section{ANALYSIS OF URBAN DEVELOPMENT PATTERNS, 2001-11}

Not surprisingly, given the policy emphasis on outward suburban development, more than three-quarters of Calgary's new housing built between 2001 and 2011 was located in the expansion area (see Figures 4 and 5). Relatively high-density suburban growth led Calgary to consume less land compared with the previous decade ( 2 ha per 100 new residents in 2001-2011 versus 6.5 ha in 1991-2001). ${ }^{15}$ Overall, the density of the built-up urban area increased in the first decade of the 21 st century due to denser suburban growth and modest intensification in core areas.

Because of long-term decline in average household size, the housing stock grew faster than the population, and therefore, the dwelling unit density of the urban area increased by more than the population density (18 per cent versus 14 per cent). The density of the existing urbanized area is lower than that in the expansion area, suggesting the creation of a higher-density ring of new subdivisions around the existing urban area. Not only was intensification insufficient to offset population loss in the existing built-up urban area, but as Figure 5 indicates, population loss is also occurring in established areas of the city. Additional housing would be needed to increase the population of the existing urban area.

15 For each city, 2001-2011 metrics are compared to 1991-2001 values in Figures 14 and 15. 
Region-wide, 69 per cent of all new dwellings were in the form of single detached houses. Most of the remainder was low-rise attached dwellings - rowhouses, duplexes, apartments and condos under five storeys. Most construction of the latter type occurred in the expansion area, boosting outer suburban density relative to that of the older suburbs. Most mid- and highrise development has taken place in the built-up urban area, although this form represents only four per cent of total construction. Interestingly, the number of detached dwellings within the existing urban area declined in absolute terms. This decline may be the result, at least in part, of demolition to make way for higher-density housing forms.

Of all new dwellings added to the Calgary region between 2001 and 2011, 15 per cent were near LRT stations and just under nine per cent were in designated policy areas. (Note that these categories are not exclusive, adding up to more than the total intensification percentage.) Whether this trend is the result of city policies or of market demand, it is clear that housing intensification in such areas is not trivial.

FIGURE 4: GROWTH PROFILE, CALGARY, 2001-11

A. Built-up urban area: extent, population, dwellings and density in 2001 and 2011

\begin{tabular}{|l|c|c|c|c|c|}
\hline & $\begin{array}{c}\text { Extent of built-up } \\
\text { area (ha) }\end{array}$ & Population & $\begin{array}{c}\text { Population } \\
\text { density (Pop/ha) }\end{array}$ & Dwellings & $\begin{array}{c}\text { Dwelling unit } \\
\text { density (Dw/ha) }\end{array}$ \\
\hline 2001 & 40,200 & 946,200 & 24 & 367,500 & 9 \\
2011 & 45,900 & $1,217,200$ & 27 & 490,500 & 11 \\
Change (n) & $+5,700$ & $+271,000$ & +3 & $+123,000$ & +2 \\
Change (\%) & $+14 \%$ & $+29 \%$ & $+13 \%$ & $+33 \%$ & $+17 \%$ \\
\hline
\end{tabular}

B. Change in population, dwellings, household size and density by location, 2001-11

\begin{tabular}{|l|c|r|r|r|c|}
\hline \multirow{2}{*}{ Location in region } & \multicolumn{2}{|c|}{ Population } & \multicolumn{2}{c|}{ Dwellings } & Avg. household \\
\cline { 2 - 5 } & Number & \% of total & Number & \% of total & size 2011) \\
\hline Built-up urban area (2001) & $-10,700$ & $-4 \%$ & $+26,700$ & $+21 \%$ & 2.5 \\
Rest of region & $+295,400$ & $+104 \%$ & $+102,400$ & $+79 \%$ & 2.9 \\
Total region & $+284,800$ & $100 \%$ & $+129,100$ & $100 \%$ & 2.6 \\
\hline
\end{tabular}

C. Change in housing stock by location, 2001-11

\begin{tabular}{|l|c|c|c|c|c|c|}
\hline \multirow{2}{*}{ Location in region } & \multicolumn{2}{|c|}{ Detached } & \multicolumn{2}{c|}{ Low-rise attached } & \multicolumn{2}{c|}{ Mid-high-rise (5+ storeys) } \\
\cline { 2 - 7 } & Number & $\begin{array}{c}\text { \% of all new } \\
\text { dwellings }\end{array}$ & Number & $\begin{array}{c}\text { \% of all new } \\
\text { dwellings }\end{array}$ & Number & $\begin{array}{c}\% \text { of all new } \\
\text { dwellings }\end{array}$ \\
\hline Built-up urban area (2001) & $-5,600$ & $-5 \%$ & $+16,600$ & $14 \%$ & $+4,800$ & $4 \%$ \\
Rest of region & $+74,200$ & $64 \%$ & $+24,500$ & $21 \%$ & +700 & $1 \%$ \\
Total region & $+68,600$ & $60 \%$ & $+41,100$ & $36 \%$ & $+5,500$ & $5 \%$ \\
\hline
\end{tabular}

D. Change in population and dwellings in designated areas, 2001-11

\begin{tabular}{|l|c|c|c|c|}
\hline \multirow{2}{*}{ Location in region } & \multicolumn{2}{|c|}{ Population } & \multicolumn{2}{|c|}{ Dwellings } \\
\cline { 2 - 5 } & Number & $\begin{array}{c}\text { \% of pop. } \\
\text { Growth }\end{array}$ & Number & $\begin{array}{c}\text { \% of all new } \\
\text { dwellings }\end{array}$ \\
\hline Near LRT stations & $+26,700$ & $9.4 \%$ & $+19,500$ & $15.1 \%$ \\
In or adjacent to designated Major Activity & $+20,400$ & $7.2 \%$ & $+11,300$ & $8.8 \%$ \\
Centres and the Downtown & & & & $20.6 \%$ \\
In built-up urban area (2001) & $-10,700$ & $-3.7 \%$ & $+26,700$ & 200 \\
\hline
\end{tabular}

All counts are rounded to the nearest 100 so as not to give a false impression of fine-level precision. 
FIGURE 5: URBAN DEVELOPMENT PATTERNS IN CALGARY, 2001-11

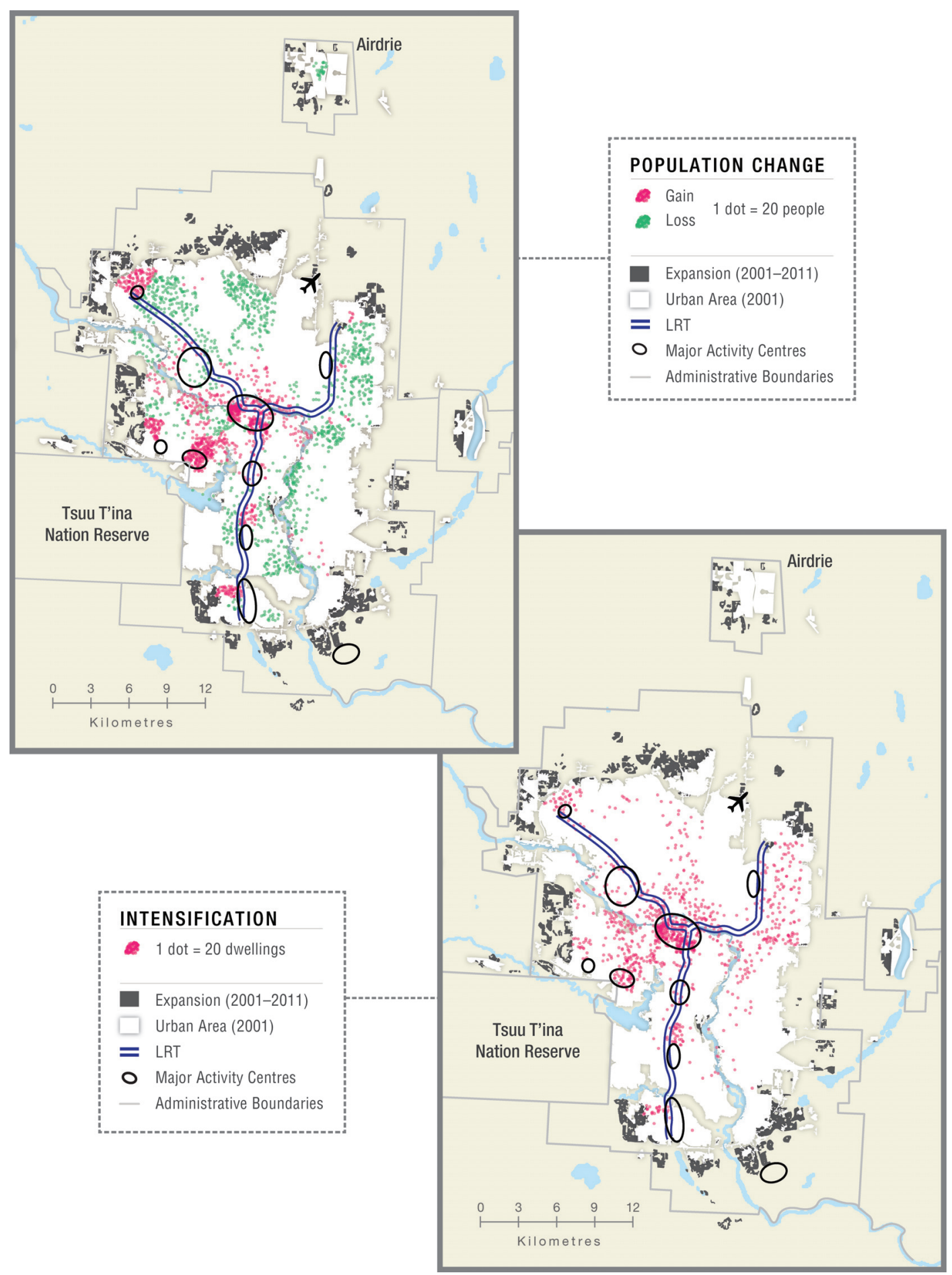

\section{A NEW POLICY REGIME?}

The core elements of Calgary's historical urban development policy regime remained consistent from the 1950s through the early 2000s. Permissive annexation facilitated the efficient and orderly accommodation of growth through urban expansion. The primary objectives were to make optimal use of existing infrastructure systems while keeping housing prices low. This system benefitted both the city and the developer-builder industry. 
Aggressive densification and intensification policies in the 2009 Municipal Development Plan and the 2012 Calgary Regional Partnership Plan represent a significant shift from established practices, so it is no surprise that they have been controversial. Developer and builder industry groups have voiced opposition to the city plan, characterizing the intensification goals as a "suburban development freeze." 16 After intense lobbying from these groups, council reduced the original suburban density target of 70 people plus jobs per hectare to 60. Although Mayor Naheed Nenshi supports the plans and their intensification goals, he has argued that achieving the lower target will accomplish little as recent subdivision plans already exceed it. (This statement is given some support by our analysis.) The Mayor and development industry organizations have engaged in an ongoing war of words over urban development issues. Nenshi's re-election has settled the issue for the time being, but the new policy's long-term feasibility and durability remain in question.

Ultimately, the plan will be implemented piece by piece through decisions of city council. Although council adopted the plan as its official policy, it has been inclined to reject mediumand high-density development proposals at transit stations when they are opposed by nearby residents. So too has it consistently opposed blanket permission for the as-of-right creation of secondary suites. At the same time, the city concedes that planning policies in place since the 1970s to promote population and employment growth downtown and in CTrain stations and corridors have been less than successful. ${ }^{17}$ This finding calls into question the feasibility of the plan's intensification goals. If the forecast city population of 2.2 million by 2076 is realized, the density of the currently urbanized area would have to double. ${ }^{18}$ This outcome will not transpire unless elected officials change their pattern of decision making.

More intensification and denser suburbs are expected to enable the accommodation of forecast growth within current municipal boundaries while enabling the city to maintain its share of the regional population. Still, the defection of some rural municipalities from the Calgary Regional Partnership renders consensus elusive. At present, the city-centred development model is enforced by Calgary's control over the water supply. Should this situation change, satellite communities and rural municipalities will lose their incentive to participate in regional planning.

In sum, Calgary may be at the cusp of policy regime change as the policy paradigm has shifted in focus from economic efficiency to livability and environmental sustainability. The new paradigm is expressed in current city and Calgary Regional Partnership planning policies. Yet opposition from influential stakeholders, combined with weak and unstable regional governance institutions and inconsistent support from the province and some local politicians, renders the current urban development policy regime unstable.

\footnotetext{
16 Sherri Zickefoose and Don Braid, "Mayor Nenshi in Dispute with Calgary Homebuilders," Calgary Herald, February 22, 2013, XX.

17 City of Calgary, Calgary Transportation Plan (Calgary, 2005), 16.

18 City of Calgary, Calgary Snapshots (Calgary, 2013), 51-53.
} 


\section{Edmonton}

Edmonton's municipal and regional planning institutions are similar to those of Calgary. Unlike Calgary, however, Edmonton is surrounded by other large urban settlements (see Figure 1). Located on the city's northwest flank, St. Albert, which was once a small French-Canadian village, now has more than 60,000 residents. Fort Saskatchewan, with a population of more than 19,000 , is located to the city's northeast. The unincorporated community of Sherwood Park, in Strathcona County, now has more than 60,000 residents. Major employment centres are also found beyond the city limits. Fort Saskatchewan and Strathcona County are home to major industrial sites associated with the oil and chemical industries, and the international airport is located between Edmonton and Leduc. (By contrast, the Calgary airport and associated employment lands are within the city limits.) Today, more than one in five jobs in the region is outside the City of Edmonton. ${ }^{19}$

Fragmented municipal government has been a persistent source of conflict. The city opposes intermunicipal competition for investment and expects to capture the fiscal benefits of industrial growth. For decades, however, its attempts to annex outlying municipalities have been rebuffed. As in Calgary, water supply is a driver of intermunicipal conflict and collaboration, as most suburban municipalities obtain their water from the city.

The City of Edmonton's first "summary plan" was approved in 1963, leading to the preparation of a comprehensive General Plan between 1967 and 1971. Subsequent general plans were adopted in 1980, 1989, 1998 and 2010. Until its demise, the Edmonton RPC also maintained an active planning program, preparing non-binding regional plans in 1952 and 1961.

Throughout this period, the RPC offered planning assistance to small municipalities - Leduc, Stony Plain, Mayerthorpe, Spruce Grove and Devon - including developing general plans and undertaking planning studies. Revision of the metropolitan plan stalled in the mid-1970s due to controversy and litigation over Edmonton's proposal to annex neighbouring St. Albert, Fort Saskatchewan and the urbanized portion of Strathcona County. Only in 1984, after the RPC's jurisdiction was split into metropolitan and non-metropolitan parts, was the next and final regional plan approved.

The dissolution of the RPC in the mid-1990s inaugurated a period of disjointed planning and ongoing distrust between the city and its neighbours. The RPC's attempt to transform itself into a voluntary "forum" ultimately failed, and the 2001 report of the provincially initiated Capital Region Governance Review was shelved. By 2008, the situation had become so intractable that the provincial government unilaterally established the Capital Region Board with compulsory membership. The body was charged with developing a regional plan with which municipal decisions must not conflict. In addition, the Board had to approve, among other municipal actions, all proposed development projects that affected more than one municipality, subdivisions planned to contain more than 1,000 residents and major industrial developments within five kilometres of a city boundary. As all decisions must be approved by 17 of the 24 member municipalities representing 75 per cent of the population (a formula that gives Edmonton a de facto veto under most circumstances), the Board, unsurprisingly, is not popular with the city's neighbouring municipalities.

19 Capital Region Board, Growing Forward: The Capital Region Growth Plan (Edmonton, 2009), Appendix I, 37. 
Although a regional plan was adopted in 2009 (by a vote of 19 to 6), conflict continues, with municipalities battling over major development approvals and competing for economic development. At present, by virtue of the proliferation of exurban industrial development, the four rural counties capture 70 per cent of tax revenue from industrial property, while Edmonton and its urban satellites receive only 30 per cent. ${ }^{20}$ In 2007, Strathcona County amended its plan to designate an urban reserve area northeast of Sherwood Park that could ultimately accommodate 200,000 residents. ${ }^{2 l}$ Earlier this year, the City of Edmonton initiated a proposal, opposed by Leduc County, to annex 15,600 hectares on its south flank, including the international airport. ${ }^{22}$ Frustrated with the ongoing conflict, then-Minister of Municipal Affairs Doug Griffiths mused publicly about amalgamating the region's 24 municipalities into five or six units, a position later endorsed by the Edmonton Chamber of Commerce. (Griffiths was removed from the portfolio in December 2013 after the politically disastrous introduction of coercive new regional planning legislation. His successor, Ken Hughes, dropped all rhetoric of provincial pre-emption.)

\section{URBAN EXPANSION POLICIES}

As in Calgary, Edmonton has long pursued growth through comprehensive planning and orderly "staging" of fully serviced contiguous development within city boundaries. The 1967 city plan contained a 15-year residential and industrial staging scheme in which subdivisions were to be comprehensively planned around "town centres" with a mix of housing types, shops, schools and recreational amenities. Although detailed in its descriptions, the plan contained few directives for implementation, and its growth scheme was rendered obsolete by faster-than-expected growth in the subsequent decade.

By the mid-1970s, the city's supply of land suitable for industry was dwindling. At this point, Edmonton revived an earlier plan to annex Fort Saskatchewan, St. Albert, all of Strathcona County, including urban Sherwood Park, and portions of Leduc and Parkland counties. After months of arguments before the provincial Local Authorities Board, the annexation was approved. The approval was later overturned by the provincial cabinet, which authorized the annexation of a broad swath of rural land while leaving intact separately incorporated urbanized areas with their rich industrial tax base. This decision gave Edmonton room to expand, however, and subsequent municipal plans and the 1984 Edmonton Metropolitan RPC plan reiterated the policy of encouraging contiguous, fully serviced urban expansion while discouraging outlying and country residential development on wells and septic tanks.

The Capital Region Board's 2009 "growth plan," Growing Forward, is more specific and directive than Edmonton's past and current municipal plans in that it designates and sets density targets for "priority growth areas" in which virtually all growth is to occur and directs country residential development to specific zones (see Figure 6). The density targets are 30 per cent higher than existing built densities and approximately 10 per cent higher than adopted municipal targets. The Capital Region Board forecasts that achieving these targets would result in the consumption of $61 \mathrm{~km}^{2}$ less rural land by 2044 , relative to the continuation of current trends. ${ }^{23}$

\footnotetext{
20 David Staples, "Time to End Industrial Tax Rip Off in Edmonton Region," Edmonton Journal, August 6, 2013, XX.

21 Susan Ruttan, “New City Rising,” Edmonton Journal, March 29, 2007, XX.

22 Jodie Sinnema, “Annexation Fight Brews with Leduc," Edmonton Journal, March 14, 2013, XX.

23 Capital Region Board, Growing Forward (Edmonton, 2010), Dec. Addendum, section. 3.5.
} 


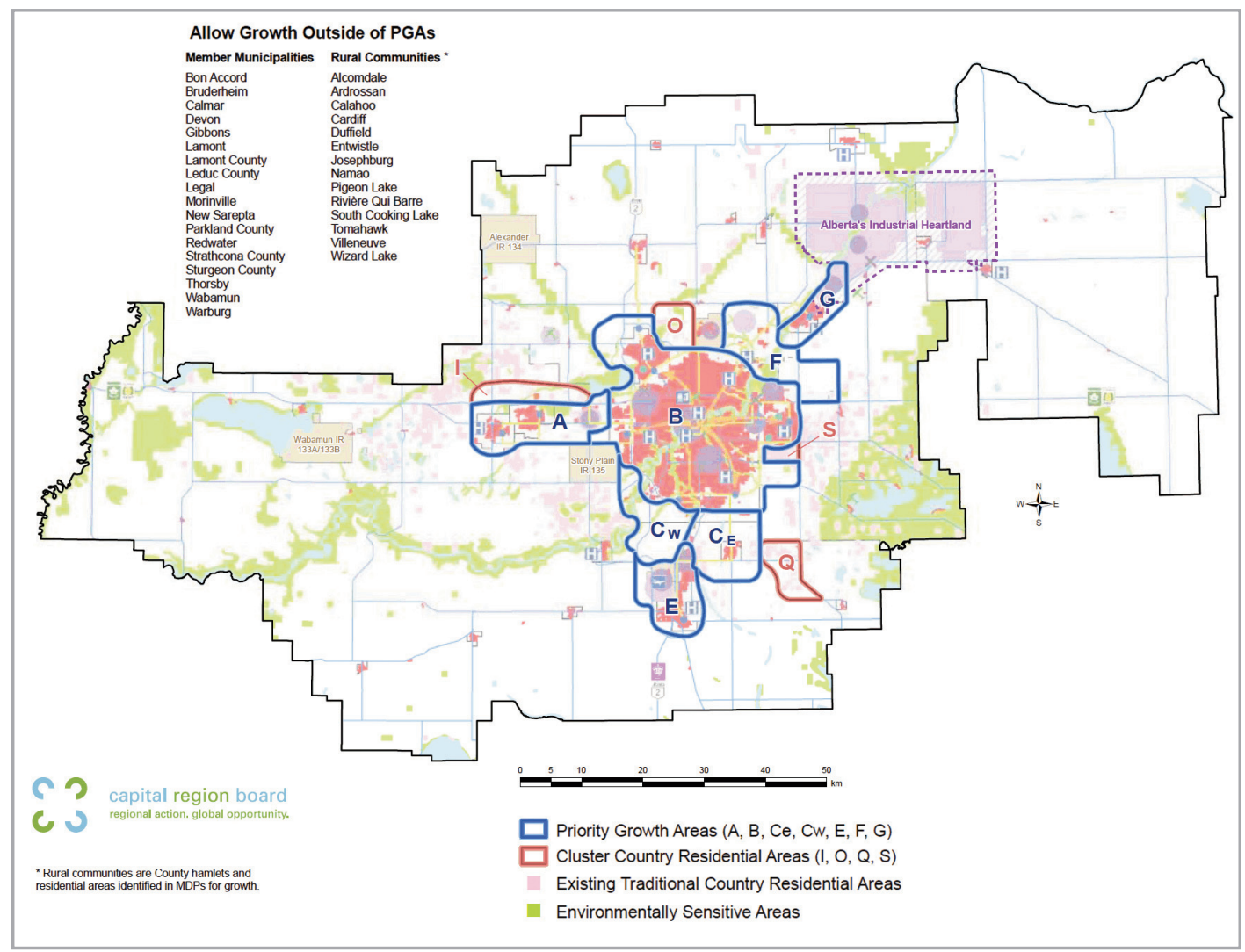

\section{INTENSIFICATION POLICIES}

Edmonton's municipal plans place little emphasis on intensification. Successive plans have devoted considerable attention to blight and the depopulation of established areas due to household change and corresponding underutilization of infrastructure capacity. The 2010 plan reiterates past policies calling for the "promotion" of high-density housing in the downtown core and general intensification across the urban area, although the means of implementation is undefined.

Reflecting concern over rising automobile congestion and the need to encourage greater use of the new LRT line that opened in 1978, the 1980 plan called for the decentralization of office employment to town centres, transit station areas, shopping centres and commercial strips throughout the city. The 1989 and 1998 plans were more modest, merely identifying "activity centres." The 2010 plan and its companion Transportation Master Plan call for transit-oriented development around present and future LRT stations and routes, but neither the stations nor the routes are mapped and performance measures and targets for nodes and corridors are still in development. The Capital Region Board, however, predicts that 144,000 residents will be added through intensification within city limits if LRT and bus network expansion plans proceed, associated nodes and corridors are fully exploited and the Edmonton City Centre Airport site is comprehensively redeveloped. ${ }^{24}$

24 Ibid., Addendum, Appendix A.3. 


\section{ANALYSIS OF URBAN DEVELOPMENT PATTERNS, 2001-11}

Spatial analysis shows that Edmonton's urban development pattern is broadly similar to Calgary's (see Figures 7 and 8). The distribution of growth between the built-up urban and expansion areas was roughly the same in both cities, with about 75 per cent of new dwellings constructed in "greenfield" suburbs. Denser suburban growth has led to the more efficient consumption of rural land ( 3 ha per 100 new residents in the 2001-11 period versus 7 ha in 1991-2001). One-third of all new dwellings in the expansion area were in the form of low-rise attached units.

Edmonton's built-up urban area became marginally denser over the 2001-11 decade. Most mid- and high-rise development occurred in the built-up urban area, principally in the downtown core, This development, however, represents only two per cent of all housing growth. Virtually all population growth occurred in the expansion area; the construction of new dwellings in core areas was insufficient to offset population loss in middle-ring suburbs.

As Edmonton does not precisely map nodes in its municipal plan, the only areas within the built-up urban area analyzed are station areas on Edmonton's single LRT line. Over the decade, the population of station areas increased by 10,400 (nine per cent of total population growth), and the number of dwellings by 7,400, even as the overall population of the built-up urban area declined. This is a promising finding as the city contemplates transit-oriented development strategies on existing and future LRT lines.

\section{A STABLE POLICY REGIME}

Edmonton has maintained a consistent urban development policy regime throughout the postwar period. The efficiency of infrastructure and service provision remains the paramount policy objective. Growth is expected to occur primarily through fully serviced suburban expansion. To this end, the city is once again seeking to annex neighbouring territory. As in Calgary, comprehensively planned residential urban expansion in Edmonton and surrounding jurisdictions benefits the developer-builder industry and municipalities. While the city plans to expand its LRT system with several new lines supported by transit-oriented development in stations and corridors, the planning process is only just getting under way (much will depend on external financing). It will be many years before these projects begin to influence urban form.

Destructive competition between municipalities, primarily for industrial but also for residential growth, remains a persistent destabilizing factor in Edmonton's urban development policy regime. In the absence of a metropolitan-scale amalgamation - an occasionally discussed but politically untouchable proposal - Edmonton will continue to capture only a small portion of non-residential property tax revenue. Unwilling to impose solutions on municipalities, the province has responded by creating the Capital Region Board to mediate intermunicipal disputes. Most of the municipalities accept the Capital Region Board's plan because the benefits of growth are dispersed across all municipalities and the one municipality with the most to lose is unable to influence the regional policy agenda. Whatever happens, the Edmonton region's general pattern of expansion-oriented urban development is unlikely to change significantly in the future. 
FIGURE 7: GROWTH PROFILE, EDMONTON, 2001-11

A. Built-up urban area: extent, population, dwellings and density in 2001 and 2011

\begin{tabular}{|l|c|c|c|c|c|}
\hline & $\begin{array}{c}\text { Extent of built-up } \\
\text { area (ha) }\end{array}$ & Population & $\begin{array}{c}\text { Population } \\
\text { density (Pop/ha) }\end{array}$ & Dwellings & $\begin{array}{c}\text { Dwelling unit } \\
\text { density (Dw/ha) }\end{array}$ \\
\hline 2001 & 35,300 & 859,700 & 24 & 343,600 & 10 \\
2011 & 42,000 & $1,072,900$ & 26 & 448,800 & 11 \\
Change (n) & $+6,700$ & $+213,200$ & +2 & $+105,200$ & +1 \\
Change (\%) & $+19 \%$ & $+25 \%$ & $+5 \%$ & $+31 \%$ & $+10 \%$ \\
\hline
\end{tabular}

B. Change in population, dwellings, household size and density by location, 2001-11

\begin{tabular}{|l|c|r|r|r|c|}
\hline \multirow{2}{*}{ Location in region } & \multicolumn{2}{|c|}{ Population } & \multicolumn{2}{c|}{ Dwellings } & Avg. household \\
\cline { 2 - 5 } & Number & \% of total & Number & $\%$ of total & (in 2011) \\
\hline Built-up urban area (2001) & $-5,000$ & $-2 \%$ & $+19,700$ & $+18 \%$ & 2.4 \\
Rest of region & $+226,300$ & $+102 \%$ & $+90,200$ & $+82 \%$ & 2.8 \\
Total region & $+221,300$ & $100 \%$ & $+109,900$ & $100 \%$ & 2.5 \\
\hline
\end{tabular}

C. Change in housing stock by location, 2001-11

\begin{tabular}{|l|c|c|c|c|c|c|}
\hline \multirow{2}{*}{ Location in region } & \multicolumn{2}{|c|}{ Detached } & \multicolumn{2}{c|}{ Low-rise attached } & \multicolumn{2}{c|}{ Mid-high-rise (5+ storeys) } \\
\cline { 2 - 7 } & Number & $\begin{array}{c}\text { \% of all new } \\
\text { dwellings }\end{array}$ & Number & $\begin{array}{c}\text { \% of all new } \\
\text { dwellings }\end{array}$ & Number & $\begin{array}{c}\text { \% of all new } \\
\text { dwellings }\end{array}$ \\
\hline Built-up urban area (2001) & $-2,000$ & $-2 \%$ & $+9,000$ & $10 \%$ & $+2,200$ & $2 \%$ \\
Rest of region & $+54,100$ & $59 \%$ & $+27,100$ & $30 \%$ & +700 & $1 \%$ \\
Total region & $+52,100$ & $57 \%$ & $+36,100$ & $40 \%$ & $+2,900$ & $3 \%$ \\
\hline
\end{tabular}

D. Change in population and dwellings in designated areas, 2001-11

\begin{tabular}{|l|r|r|r|c|}
\hline \multirow{2}{*}{ Location in region } & \multicolumn{2}{|c|}{ Population } & \multicolumn{2}{|c|}{ Dwellings } \\
\cline { 2 - 5 } & Number & $\begin{array}{c}\text { \% of pop. } \\
\text { Growth }\end{array}$ & Number & $\begin{array}{c}\text { \% of all new } \\
\text { dwellings }\end{array}$ \\
\hline Near LRT stations & $+10,400$ & $9 \%$ & $+7,400$ & $7 \%$ \\
In built-up urban area (2001) & $-5,000$ & $-2 \%$ & $+19,700$ & $18 \%$ \\
\hline
\end{tabular}

All counts are rounded to the nearest 100 so as not to give a false impression of fine-level precision. 

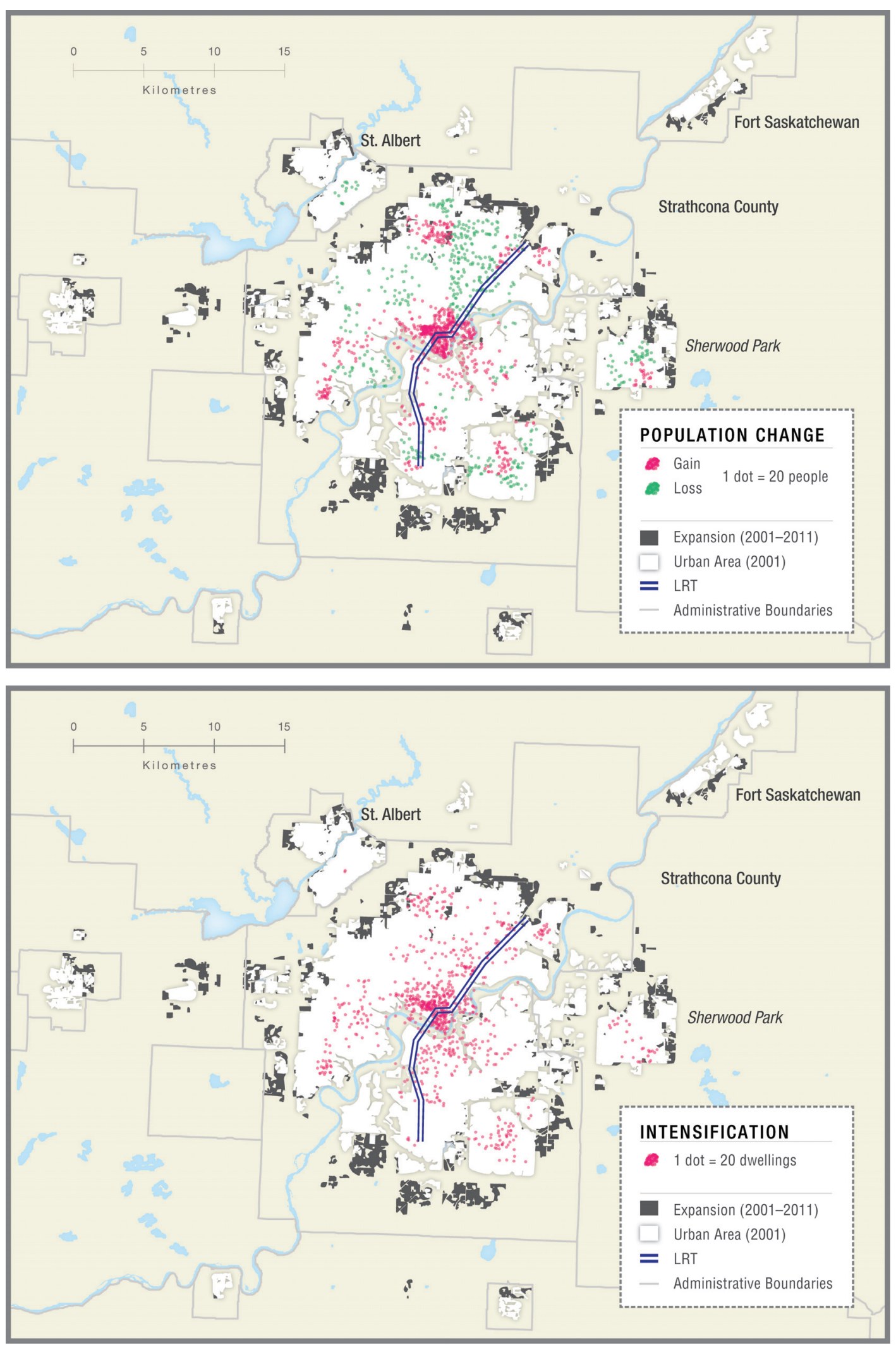


\section{COUNTERPOINT: VANCOUVER AND TORONTO}

Toronto and Vancouver have at various points in their history faced urbanization-related challenges similar to those experienced in Calgary and Edmonton. The configuration of their paths of historical development, however, differs in important respects. This section presents an overview of Toronto and Vancouver's urban development policy regimes - how they are structured and how they have changed over time - in relation to a spatial analysis of their urban development patterns and concludes with an assessment of their future prospects.

\section{Vancouver}

British Columbia's Lower Mainland has long been divided into a patchwork of municipalities, of which the City of Vancouver is but one (see Figure 1). ${ }^{25}$ As a result, Alberta-style incremental annexation was never an option. Instead, provincial and local governments incrementally developed regional institutions to coordinate municipal actions. Intermunicipal sewer and water districts created in 1913 and 1924 established an enduring institutional template characterized by equitable treatment of municipalities and openness toward new members. This approach enabled the extension of trunk water and sewer systems in relation to urban growth while minimizing conflict over apportioning costs. The province established a Lower Mainland Regional Planning Board (LMRPB) in 1949. Similar to Alberta's RPCs, it provided planning assistance to smaller local governments and developed a broad-brush regional plan to which local plans had to conform. By the early 1970s, these earlier regional institutions were absorbed into provincially created, multi-purpose municipal federations called "regional districts." The Lower Mainland was divided into four such districts, including the Greater Vancouver Regional District (GVRD), in 1967.

Several regional policy statements and plans have been adopted since 1945. The LMRPB's Official Regional Plan (ORP) came into effect in 1966 and was revised in 1980. The GVRD produced its own policy statement, Livable Region 1976/1986, in 1975. Its ideas were rolled into the 1980 ORP revision. The GVRD's planning program was interrupted in 1983 when, as part of a broad-based retrenchment program, the Social Credit government abolished the regional districts' planning authority and annulled existing regional plans. (This move presaged Alberta's abolition of regional planning commissions a decade later.) Municipalities, however, continued to cooperate voluntarily on regional planning initiatives. The province reauthorized regional district planning in 1995. Under the new legislation, a "regional growth strategy" comes into effect only with the consent of all affected local governments (there is no legislative requirement that local municipal plans conform to the strategy). The GVRD's Livable Region Strategic Plan (LRSP) was adopted in 1996, and was comprehensively revised in 2011. In 2007, the GVRD board voted unanimously to rename itself "Metro Vancouver," perhaps a sign that regional government, once strongly resisted by municipalities and residents alike, had come of age.

${ }^{25}$ For an overview of local and regional planning in Vancouver, the Lower Mainland and in British Columbia more generally, see Susan E. Corke, Land Use Controls in British Columbia (Toronto: University of Toronto, Centre for Urban and Community Studies, 1983); and Mike Harcourt, Ken Cameron, and Sean Rossiter, City Making in Paradise: Nine Decisions that Saved Vancouver (Vancouver: Douglas and McIntyre, 2007). 


\section{URBAN EXPANSION POLICIES}

The LMRPB enunciated two enduring planning principles in the 1950s. First, agricultural land would be comprehensively protected to preserve productive farmland. Second, all suburban development would be fully serviced, contiguous to existing urban areas and sufficiently dense to support the economic provision of urban services. To these ends, the 1966 ORP specified where urban residential, industrial, recreational and agricultural uses were and were not permitted.

Farmland protection (and hence urban containment) was reinforced by the establishment of the province-wide Agricultural Land Reserve (ALR) in $1973 .{ }^{26}$ Building on the ALR to include floodplains, forests, ecologically important lands and major parks and recreation areas, the 1996 GVRD plan established a Green Zone of about 210,000 hectares to "define the limit to urban expansion., ${ }^{27}$ In the 2011 plan, the Green Zone was replaced by three "non-urban" land use designations where urban development is prohibited. Similarly, the Fraser Valley Regional District's 2004 plan defines urban and non-urban zones.

Under the rubric of "complete communities," the 1996 plan called for municipalities to promote tenures and access to amenities in urban expansion areas, greater jobs-housing balance and diversity of housing types. These policies were reiterated in the 2011 plan, which included a supplemental requirement for neighbourhood-level planning for active transportation. The promotion of denser suburban environments has been successful. Our spatial analysis found that attached low-rise accounted for half of all construction in expansion areas, contributing to higher suburban densities. (This figure compares to 24 per cent of expansion housing in Calgary, 26 per cent in Edmonton and 33 per cent in Toronto.)

\section{INTENSIFICATION POLICIES}

Intensification has been spurred by physical and policy limits on the supply of developable land in the Lower Mainland and by urban containment policies. To reduce congestion on river crossings, as well as development pressure on floodplain and unprotected agricultural land, the 1996 plan defined a Growth Concentration Area intended to accommodate 70 per cent of the GVRD population by 2021, up from 65 per cent in 1991. This policy built on the 1980 ORP, which set targets for new urban development in the Lower Mainland to be directed to the GVRD's urban core and to the north side of the Fraser River. The 2011 plan replaced the Growth Concentration Area with an Urban Containment Boundary, which is intended to represent the ultimate extent of urban development. As much of the land within the boundary is already urbanized, most future growth is expected to be accommodated through infill and redevelopment.

\footnotetext{
${ }^{26}$ For an overview of the politics of the Agricultural Land Reserve's creation, see Christopher Garrish, "Unscrambling the Omelette: Understanding British Columbia's Agricultural Land Reserve," B.C. Studies 136 (2002/03): 25-55; and Andrew Petter, "Sausage Making in British Columbia's NDP Government: The Creation of the Land Commission Act, August 1972-April 1973.” B.C. Studies 65 (1985): 3-33.

27 Greater Vancouver Regional District, Livable Region Strategic Plan (Vancouver, 1996), 10.
} 
Consistent with Metro Vancouver's policy objectives, the spatial analysis indicates that the vast majority of population ( 69 per cent) and housing ( 75 per cent) growth occurred within the existing built-up urban area (see Figure 9).$^{28}$ As a result, the extent of the built-up area increased by only three per cent between 2001 and 2011. Vancouver's high volume of intensification is achieved in part through the demolition and replacement of lower-density housing forms. The number of detached dwellings, therefore, has declined significantly in absolute terms, both within the built-up urban area and in the region as a whole. Low-rise attached dwellings made up the most prevalent housing form constructed between 2001 and 2011, with more than 80 per cent located within the existing built-up urban area. High-rise apartments accounted for 20 per cent of the net increase in the overall housing stock. A high intensification rate, combined with more compact suburban development, increased the overall density of built-up areas over the decade, and, unlike the Alberta cities, increased the population of the existing built-up area in absolute terms.

Starting in the 1970s, the GVRD called for concentrating growth in Regional Town Centres, transit-oriented, mixed-use nodes that would function as amenity-rich focal points for suburban communities. The nodal concept was carried forward into subsequent plans. (These are mapped in Figure 10.) The 2011 plan adds a new concept, the Frequent Transit Development Area. Of the 574,000 new dwellings expected to be built between 2006 and 2041, the plan calls for 40 per cent to be located in centres, 28 per cent to be located in Frequent Transit Development Areas and the remainder to be located in the residual "general" urban area. Similarly, 77 per cent of new jobs are to be located in centres and transit corridors. ${ }^{29}$ Our spatial analysis found that much new residential development has indeed occurred in SkyTrain station areas and in Regional Town Centres. (These categories are not mutually exclusive; some designated centres are focused on SkyTrain stations.) The spatial analysis also shows that approximately 20 per cent of regional population growth and 24 per cent of housing growth was in the vicinity of transit stations.

\section{FULL STEAM AHEAD, BUT CLOUDS ON THE HORIZON}

The Lower Mainland's two regional districts forecast robust population growth: from 2.3 million to 3.4 million between 2011 and 2041 in Metro Vancouver, and from 280,000 to 450,000 between 2011 and 2030 in the Fraser Valley Regional District. If the Urban Containment Boundary holds, virtually all of Metro Vancouver's long-term growth will take place through intensification. Reinforced by collaborative decision-making within the regional district, support for urban containment among the public and municipal leaders is strong, and the development industry has long since embraced high- and mid-rise infill and redevelopment projects.

Vancouver's longstanding intensification-oriented sustainability policy regime remains stable for now, but pressures are building that may destabilize it in the future. First, the province's support for higher-order transit expansion since the 1970s has been inconsistent. Arbitrary decisions and cancelled projects in the 1990s undermined the development of outlying centres.

\footnotetext{
${ }^{28}$ It should be noted that a proportion of what is classified as intensification is in fact the "filling in" of existing scattered exurban development, especially in Surrey and Langley District. Even if this were categorized as expansion rather than intensification, the intensification rate would still be the highest of the four cities.

${ }^{29}$ Metro Vancouver, Metro Vancouver 2040 - Shaping Our Future (Vancouver, 2011), Table 2.
} 
The 2010 completion of the Canada (SkyTrain) Line connecting downtown Vancouver to Richmond and the airport, combined with the imminent construction of the Evergreen Line to Coquitlam, will go some way toward delivering on the promise of integrating intensified land use with transportation capacity. In the absence of improved transportation options, however, intensification may generate further congestion.

Second, Vancouver's housing costs have in recent years become unaffordable to the majority of the city's residents, especially in established areas that are served well by transit. The high cost of housing may force lower-income households to locate in lower-cost peripheral locations, a situation that would undermine regional equity and the benefits of transit-oriented intensification. Vancouver's high housing costs have many causes, and physical or policyinduced land scarcity is certainly one of them..$^{30}$ Time will tell if a diminishing supply of land available for urban development will generate irresistible pressure to relax land use controls.

FIGURE 9: GROWTH PROFILE, VANCOUVER, 2001-11

A. Built-up urban area: extent, population, dwellings and density in 2001 and 2011

\begin{tabular}{|l|c|c|c|c|c|}
\hline & $\begin{array}{c}\text { Extent of built-up } \\
\text { area (ha) }\end{array}$ & Population & $\begin{array}{c}\text { Population } \\
\text { density (Pop/ha) }\end{array}$ & Dwellings & $\begin{array}{c}\text { Dwelling unit } \\
\text { density (Dw/ha) }\end{array}$ \\
\hline 2001 & 73,100 & $2,141,600$ & 29 & 845,100 & 12 \\
2011 & 76,300 & $2,500,000$ & 33 & $1,023,400$ & 13 \\
Change (n) & $+3,200$ & $+361,600$ & +4 & $+180,500$ & +2 \\
Change (\%) & $+4 \%$ & $+17 \%$ & $+14 \%$ & $+21 \%$ & $+16 \%$ \\
\hline
\end{tabular}

B. Change in population, dwellings, household size and density by location, 2001-11

\begin{tabular}{|l|c|c|c|c|c|}
\hline \multirow{2}{*}{ Location in region } & \multicolumn{2}{|c|}{ Population } & \multicolumn{2}{c|}{ Dwellings } & Avg. household \\
\cline { 2 - 5 } & Number & \% of total & Number & \% of total & size11) \\
\hline Built-up urban area (2001) & $+250,900$ & $69 \%$ & $+137,700$ & $75 \%$ & 2.7 \\
Rest of region & $+115,300$ & $31 \%$ & $+45,000$ & $25 \%$ & 2.8 \\
Total region & $+366,200$ & $100 \%$ & $+182,700$ & $100 \%$ & 2.7 \\
\hline
\end{tabular}

C. Change in housing stock by location, 2001-11

\begin{tabular}{|l|c|c|c|c|c|c|}
\hline \multirow{2}{*}{ Location in region } & \multicolumn{2}{|c|}{ Detached } & \multicolumn{2}{c|}{ Low-rise attached } & \multicolumn{2}{c|}{ Mid-high-rise (5+ storeys) } \\
\cline { 2 - 7 } & Number & $\begin{array}{c}\text { \% of all new } \\
\text { dwellings }\end{array}$ & Number & $\begin{array}{c}\text { \% of all new } \\
\text { dwellings }\end{array}$ & Number & $\begin{array}{c}\text { \% of all new } \\
\text { dwellings }\end{array}$ \\
\hline Built-up urban area (2001) & $-39,400$ & $-27 \%$ & $+108,700$ & $75 \%$ & $+36,200$ & $25 \%$ \\
Rest of region & $+15,500$ & $11 \%$ & $+22,300$ & $15 \%$ & $+2,300$ & $2 \%$ \\
Total region & $-23,900$ & $-16 \%$ & $+131,000$ & $90 \%$ & $+38,500$ & $27 \%$ \\
\hline
\end{tabular}

D. Change in population and dwellings in designated areas, 2001-11

\begin{tabular}{|l|r|r|r|c|}
\hline \multirow{2}{*}{ Location in region } & \multicolumn{2}{|c|}{ Population } & \multicolumn{2}{|c|}{ Dwellings } \\
\cline { 2 - 5 } & Number & $\begin{array}{c}\text { \% of pop. } \\
\text { Growth }\end{array}$ & Number & $\begin{array}{c}\text { \% of all new } \\
\text { dwellings }\end{array}$ \\
\hline Near SkyTrain stations & $+74,900$ & $20 \%$ & $+42,900$ & $23 \%$ \\
In Regional Town Centres & $+61,400$ & $17 \%$ & $+34,700$ & $19 \%$ \\
In built-up urban area (2001) & $+250,900$ & $69 \%$ & $+137,700$ & $75 \%$ \\
\hline
\end{tabular}

All counts are rounded to the nearest 100 so as not to give a false impression of fine-level precision.

30 High housing costs may also stem from global investment in Vancouver's real estate and the wide availability, at
least until recently, of relatively low mortgage rates. 
FIGURE 10: URBAN DEVELOPMENT PATTERNS, VANCOUVER, 2001-11
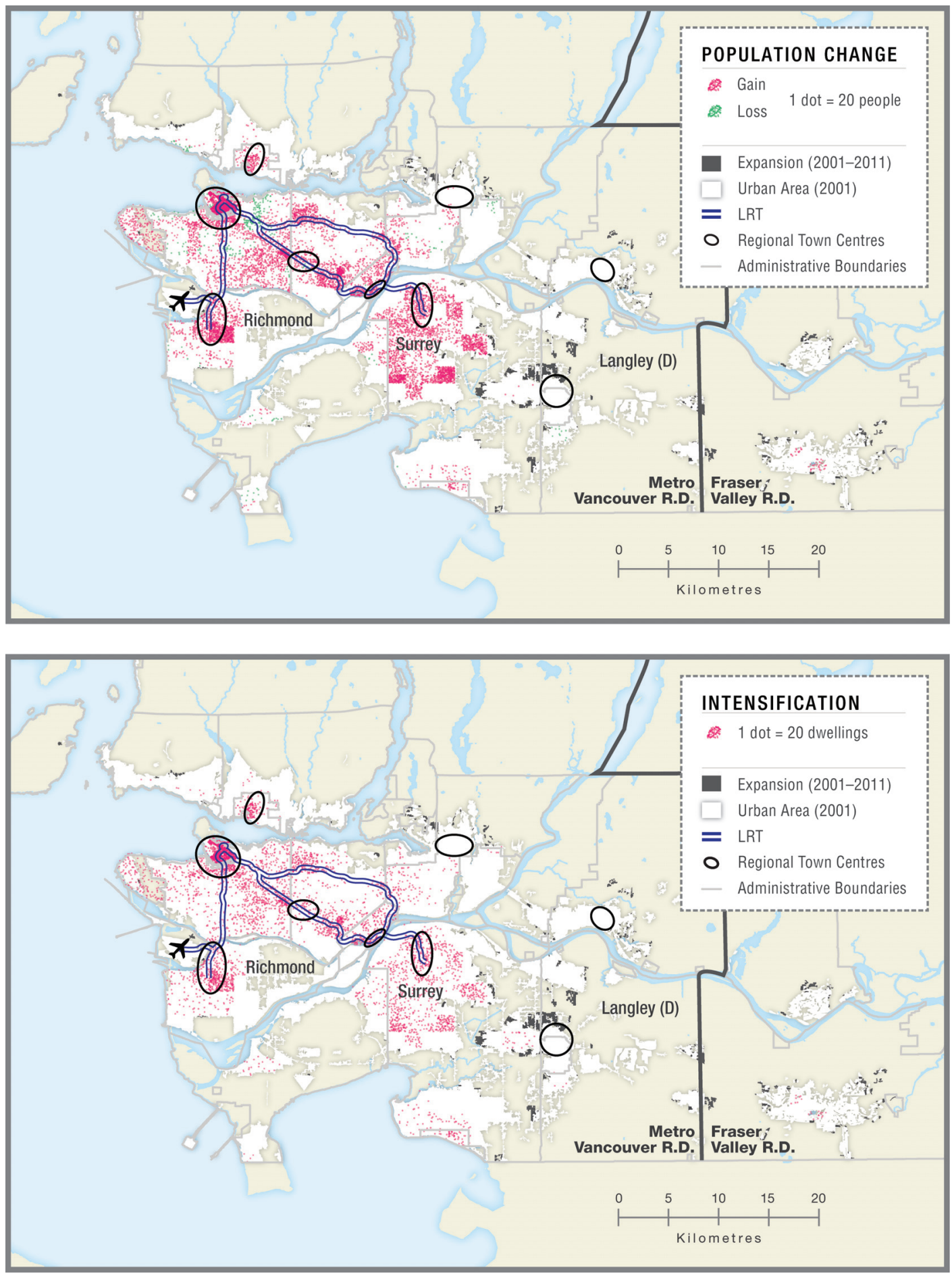


\section{Toronto}

Toronto ended its policy of annexing surrounding communities after the First World War, a move that led to disjointed and poorly serviced fringe development. ${ }^{31}$ Rapid growth after the Second World War led the province to impose a two-tier local government structure on the City of Toronto and its 12 immediate suburbs, each of which was represented on the new Metro council. The Metropolitan Toronto Planning Board (MTPB), which reported to the council, exercised jurisdiction over Metro and 13 surrounding townships. While Metro planned, financed and constructed major infrastructure, the MTPB influenced land subdivision decisions outside the city and developed an official plan. (At the time, the province exercised land subdivision approval authority with the advice of local planning boards.)

The MTPB successfully organized the region's urban development until the late 1960s, when growth spilled beyond its boundaries. In the early 1970s, the province chose not to expand the geographic reach of Metro or the MTPB. Instead, it reorganized the surrounding counties into two-tier "regional municipalities" with planning powers akin to Metro's. Although the province proposed a policy framework to coordinate the regional municipalities' planning, it was never enacted. At the end of the 1970s, the province embarked on a devolutionary path, transferring planning and other powers to municipalities. The province removed itself from day-to-day planning approvals, and instead, set general policies while retaining the authority to review and approve local comprehensive plans. Devolution without coordination led to robust planning within each of the region's municipalities, but it also led to disjunctures among them.

The 1988-2003 period was marked by a seesaw of provincial involvement in local and regional planning. Liberal (1985-90) and NDP (1990-95) governments imposed stronger controls on urban development and took steps to develop a regional vision, but the Conservatives (1995-2003) annulled these efforts early in their first mandate. Only in the early 2000s did the government tentatively embark on a "Smart Growth" regional planning program. The subsequent Liberal government established a new set of policies and institutions for the broader Toronto region: the Greenbelt Plan (2005), the Growth Plan for the Greater Golden Horseshoe (2006) and the creation of a regional transportation planning and operating body now called Metrolinx.

\section{URBAN EXPANSION POLICIES}

As in the other cities, policymakers have consistently pursued fully serviced and contiguous suburban development since the 1940s to maximize infrastructure efficiency. As a result, the urbanization of the Toronto region has been largely contiguous and fully serviced, and leapfrog development and new free-standing settlement areas have been discouraged. Following Vancouver's lead, the 2006 Growth Plan calls for urban expansion areas to be planned as "complete communities" that mix residential, employment and amenity uses at transitsupportive densities. Our spatial analysis found that these new suburbs are dense, containing higher proportions of attached and apartment units than the other cities studied.

31 On local and regional governance and planning in Toronto and in Ontario more generally, see Timothy Colton, Big Daddy: Frederick G. Gardiner and the Building of Metropolitan Toronto (Toronto: University of Toronto Press, 1980); Frances Frisken, The Public Metropolis: The Political Dynamics of Urban Expansion in the Toronto Region, 1924-2003 (Toronto: Canadian Scholars Press, 2008); Ted Gomme, "Municipal Planning in Ontario," (unpublished typescript, 1983); David Hulchanski, The Origins of Urban Land Use Planning in Ontario, 1900-1946 (Toronto: University of Toronto, Department of Urban and Regional Planning, 1981): Nigel H. Richardson, "Insubstantial Pageant: The Rise and Fall of Provincial Planning in Ontario," Canadian Public Administration 24, no. 4 (1981): 563-85; and Richard White, The Growth Plan for the Greater Golden Horseshoe in Historical Perspective (Toronto: Neptis Foundation, 2007). 
Environmental and agricultural land protection, however, is fragmented. A patchwork of federal, provincial and municipal policies and plans identify or protect many specific natural features, both large and small. Provincial and municipal policies also set criteria for the urbanization of agricultural land. Feature-based land protection measures and their parcel-level application have not collectively contained urban expansion, nor were they intended to do so. Over time, the province has designated three zones in which urban development is comprehensively restricted: the Niagara Escarpment (1985), the Oak Ridges Moraine (2001) and the Greenbelt (2005). While a large quantity of land remains available for urban development between the existing Toronto-centred urbanized area and the Greenbelt, the Greenbelt is, in principle, the ultimate constraint on urban expansion.

\section{INTENSIFICATION POLICIES}

Since the 1990s, provincial policy has required municipalities to accommodate growth within existing built-up areas where possible, and some municipalities have set explicit targets of their own. The 2006 Growth Plan is more ambitious, requiring all upper- and single-tier municipalities in the "inner ring" of the region - the City of Toronto and the City of Hamilton, as well as the regional municipalities of Halton, Peel, Durham and York - to accommodate a minimum of 40 per cent of new dwelling units within the existing urban area after 2015. Our spatial analysis indicates that these targets are already being exceeded at the regional scale. About half of all new dwellings constructed between 2001 and 2011 were located within the existing built-up urban area, a proportion that is higher than that in Calgary but lower than that of Vancouver (see Figures 11 and 12). Although some inner-city and suburban areas have experienced population decline, the overall population of the built-up urban area increased by more than 200,000 people over the decade, propelling an increase in overall population density.

The fact that Toronto's elevated intensification rates (more than double those of Calgary and Edmonton) predate the enactment and implementation of the provincial policies of the past decade suggests that long-term market demand for high-density housing may be driving the urban development pattern more than policy. But even if policy is simply catching up to a market shift induced by demographic change and the preferences of global real estate investors (a shift to which developers have already responded), a more coordinated development policy may lead to more efficient allocation of resources for infrastructure and servicing and the design of more attractive and balanced "complete communities."

Policies directing growth to transit nodes and corridors have existed since the 1960s, although until recently they have met with mixed success. Building on earlier municipal policies, the 2006 Growth Plan defines 25 "urban growth centres" (UGCs). Some are nodes within the existing urban fabric, some are the downtowns of free-standing cities, while others are yet to be developed. (These are mapped in Figure 12.) Our spatial analysis indicates that transitoriented development is accelerating. About 40 per cent of dwellings constructed in the existing built-up area (about 20 per cent of new housing region-wide) were built near subway stations or transit hubs designated by Metrolinx. A similar proportion was built in Urban Growth Centres designated in the 2006 Growth Plan (these categories overlap). 


\section{THE INDISPENSIBLE PROVINCE}

During the past decade the province has assumed the role of planner and coordinator for the Toronto region. The ultimate success of its policies, however, depends on its capacity to monitor municipal compliance and its willingness, if necessary, to take corrective action. Unlike in Calgary, development-industry groups have thus far accommodated themselves to the new regional planning framework (albeit voicing concern about constraints on developable land and rising housing prices), and most inner-ring municipalities are pursuing conformity with the Growth Plan in good faith. ${ }^{32}$ Still, it will be years before all municipalities' plans and zoning bylaws are brought into official conformity with provincial plans, and many years more before their impact can be assessed.

\section{FIGURE 11: GROWTH PROFILE, TORONTO, 2001-11}

A. Built-up urban area: extent, population, dwellings and density in 2001 and 2011

\begin{tabular}{|l|c|c|c|c|c|}
\hline & $\begin{array}{c}\text { Extent of built-up } \\
\text { area (ha) }\end{array}$ & Population & $\begin{array}{c}\text { Population } \\
\text { density (Pop/ha) }\end{array}$ & Dwellings & $\begin{array}{c}\text { Dwelling unit } \\
\text { density (Dw/ha) }\end{array}$ \\
\hline 2001 & 178,100 & $5,409,800$ & 30 & $1,958,100$ & 11 \\
2011 & 190,600 & $6,409,700$ & 34 & $2,416,100$ & 13 \\
Chasnge (n) & $+12,500$ & $+999,900$ & +4 & $+458,000$ & +2 \\
Chasnge (\%) & $+7 \%$ & $+18 \%$ & $+11 \%$ & $+23 \%$ & $+15 \%$ \\
\hline
\end{tabular}

B. Change in population, dwellings, household size and density by location, 2001-11

\begin{tabular}{|l|c|c|c|c|c|}
\hline \multirow{2}{*}{ Location in region } & \multicolumn{2}{|c|}{ Population } & \multicolumn{2}{c|}{ Dwellings } & Avg. household \\
\cline { 2 - 5 } & Number & \% of total & Number & \% of total & sin 2011) \\
\hline Built-up urban area (2001) & $+209,600$ & $21 \%$ & $+225,700$ & $49 \%$ & 2.8 \\
Rest of region & $+793,100$ & $79 \%$ & $+236,300$ & $51 \%$ & 3.2 \\
Total region & $+1,002,700$ & $100 \%$ & $+462,000$ & $100 \%$ & 2.9 \\
\hline
\end{tabular}

C. Change in housing stock by location, 2001-11

\begin{tabular}{|l|c|c|c|c|c|c|}
\hline \multirow{2}{*}{ Location in region } & \multicolumn{2}{|c|}{ Detached } & \multicolumn{2}{c|}{ Low-rise attached } & \multicolumn{2}{c|}{ Mid-high-rise (5+ storeys) } \\
\cline { 2 - 7 } & Number & $\begin{array}{c}\text { \% of all new } \\
\text { dwellings }\end{array}$ & Number & $\begin{array}{c}\text { \% of all new } \\
\text { dwellings }\end{array}$ & Number & $\begin{array}{c}\text { \% of all new } \\
\text { dwellings }\end{array}$ \\
\hline Built-up urban area (2001) & $-34,600$ & $-9 \%$ & $+112,900$ & $28 \%$ & $+93,400$ & $23 \%$ \\
Rest of region & $+145,100$ & $37 \%$ & $+76,800$ & $19 \%$ & $+5,500$ & $1 \%$ \\
Total region & $+113,100$ & $28 \%$ & $+189,600$ & $47 \%$ & $+98,900$ & $25 \%$ \\
\hline
\end{tabular}

D. Change in population and dwellings in designated areas, 2001-11

\begin{tabular}{|l|r|r|r|c|}
\hline \multirow{2}{*}{ Location in region } & \multicolumn{2}{|c|}{ Population } & \multicolumn{2}{c|}{ Dwellings } \\
\cline { 2 - 5 } & Number & $\begin{array}{c}\text { \% of pop. } \\
\text { Growth }\end{array}$ & Number & $\begin{array}{c}\text { \% of all new } \\
\text { dwellings }\end{array}$ \\
\hline Near subway stations or Metrolinx hubs & $+97,800$ & $10 \%$ & $+88,700$ & $19 \%$ \\
In Urban Growth Centres & $+130,600$ & $13 \%$ & $+92,100$ & $20 \%$ \\
In built-up urban area (2001) & $+209,600$ & $21 \%$ & $+225,700$ & $49 \%$ \\
\hline
\end{tabular}

All counts are rounded to the nearest 100 so as not to give a false impression of fine-level precision.

32 See Rian Allen and Philippa Campsie, Implementing the Growth Plan for the Greater Golden Horseshoe: Has the Strategic Vision Been Compromised? (Toronto: Neptis Foundation, 2013). 
FIGURE 12: URBAN DEVELOPMENT PATERNS, TORONTO, 2001-11

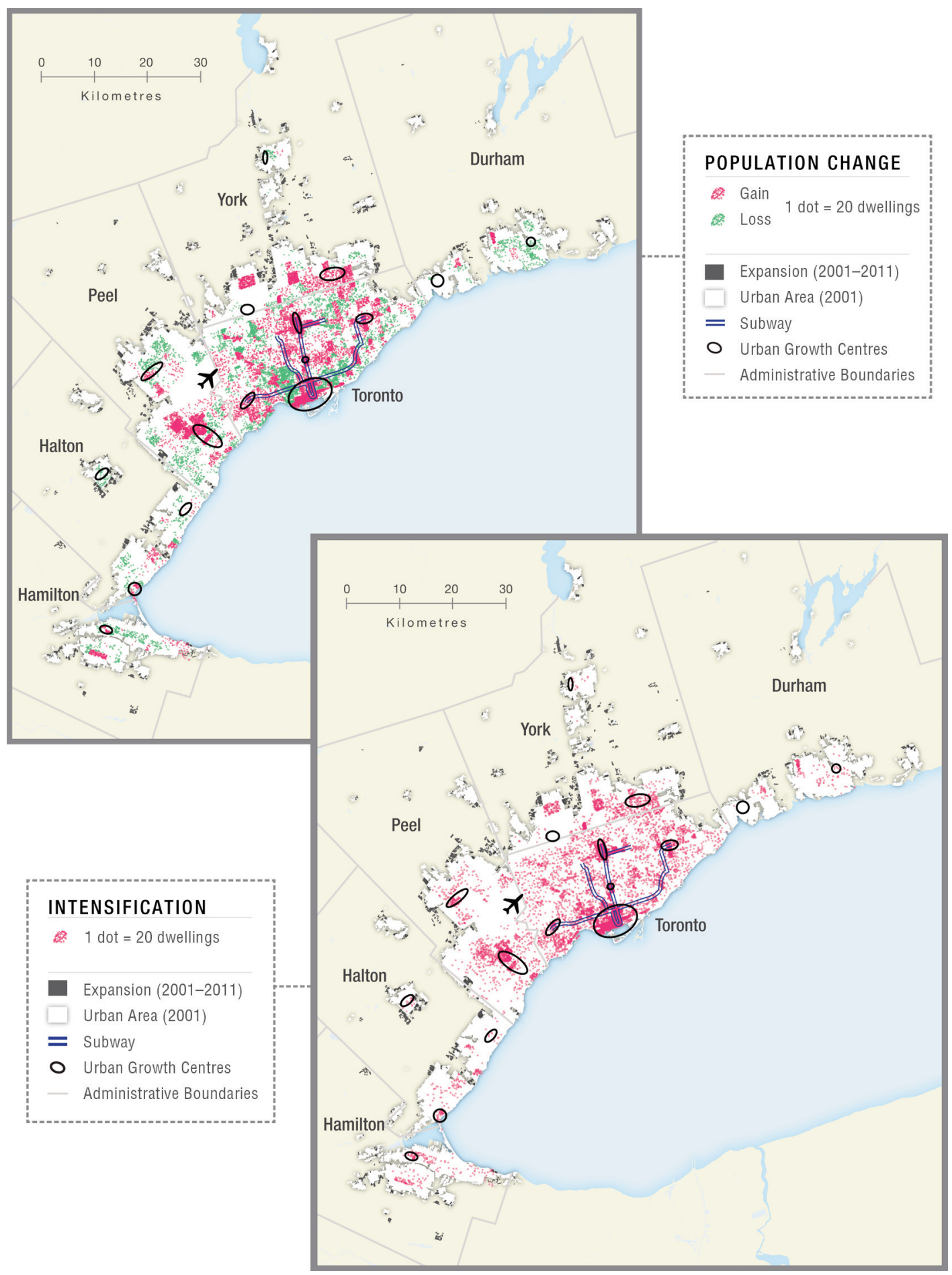




\section{CONCLUSION}

In this report, we have provided accounts of each city's postwar urban development policy regimes and related them to spatial analysis of how each city grew during the 1991-2011 period, concentrating on the latter decade. We conclude by comparing the cities and drawing lessons for the Alberta cities.

\section{Comparing Urban Development Policy Regimes}

\section{POSTWAR EFFICIENCY-ORIENTED EXPANSION POLICY REGIMES}

The policy reviews demonstrate that all four cities planned urban expansion in much the same way in the immediate postwar period. We characterize this package of ideas, institutions and policies as an efficiency-oriented expansion policy regime. In each case, authorities shared a common policy paradigm and articulated and enforced the same objectives: that urban development should be fully serviced and contiguous to existing urban areas, thereby reducing public infrastructure and servicing costs and avoiding negative externalities associated with disjointed and unserviced development. Moreover, it was generally accepted that that growth would occur through urban expansion and that redevelopment of sites within the existing urban area would play only a marginal role in accommodating additional population.

Perhaps reflecting the diffusion of policy ideas through national professional networks and training, similar policy instruments were used to pursue similar objectives. Conditional extension of linear infrastructure, subdivision control and zoning were strategically employed to produce clearly defined urban and rural zones at the regional scale and discourage scattered, low-density, exurban or "country residential" development. More recently, Vancouver, Toronto and Calgary have adopted "complete communities" policies to guide the development of new subdivisions. Suburban neighbourhoods are expected to become denser and more mixed in terms of housing types and land uses, and to be organized to facilitate walking, cycling and the economical provision of transit. In a sense, earlier postwar master-planned subdivisions were always intended to be "complete" insofar as they were oriented around shopping plazas, but today's emphasis on density, non-retail employment and fine-grained mix of uses is new.

Perhaps most systematically in Calgary and Toronto, the development of large master-planned suburban subdivisions occurred in virtual partnership with a highly consolidated developerbuilder industry that had the capacity to finance large-scale land acquisitions and pay for infrastructure in advance of development. A strong and well-organized developer-builder industry supported the system because it generated predictable profits as land was developed.

In each city, the policy regime was supported by complementary institutional structures. In the Lower Mainland, the regional water, sewer and planning boards, followed later by the regional districts, facilitated orderly urban expansion. Metro and its planning board accomplished much the same thing in 1950s and 1960s Toronto. In Alberta, incremental annexation was supported by the regional planning commissions. 


\section{PARADIGM SHIFT IN TORONTO AND VANCOUVER: THE SUSTAINABILITY-ORIENTED INTENSIFICATION REGIME}

Starting in the late 1960s in Vancouver and in the 1980s in Toronto, the earlier efficiencyoriented expansion policy regime gave way to a greater focus on environmental protection and livability. We refer to the new policy package as a sustainability-oriented intensification regime. Existing policy instruments and objectives for regulating suburban expansion remained in place, justified not solely on efficiency grounds, but also as a means of protecting rural land, maintaining inner-city vibrancy and injecting "urban" vitality into newer suburban areas.

First introduced at the regional level in Vancouver, exclusive agricultural zoning was later entrenched province-wide. Over time, this mechanism was recast as an urban containment device and extended to rural lands more broadly. Toronto's Greenbelt is similarly justified as a means of permanently protecting, for their own sake, a variety of rural land uses from urban development. While Vancouver's urban containment strategy allows little remaining land for urban expansion, Ontario policymakers have struck a balance between rural land preservation and urban expansion, all the while avoiding the imposition of an inflexible, near-term limit to urban expansion. It is unlikely that the high intensification levels observed in Vancouver in the past two decades could have been sustained without the politically popular provincial Agricultural Land Reserve.

Redirecting growth from the suburban fringe to existing built-up areas required the development of new policy instruments. Since the 1970s, Vancouver, Toronto and Calgary have designated networks of transit-oriented nodes and corridors and, more recently, adopted minimum density and other performance targets to shape development.

While initially vocal in their opposition, developers in Toronto and Vancouver have adapted to the new policy framework, becoming adept at constructing a variety of multi-household residential formats. In both cities, homebuilders' associations have voiced concern about the relationship between housing availability and prices. Successful policy implementation depends on ongoing industry cooperation.

\section{PARADIGM SHIFT IN CALGARY?}

Only very recently has the efficiency-oriented expansion policy regime been upset in Calgary. The growing interest in policies to promote livability and sustainability has been driven by concerns internal to the city, including rising traffic congestion and infrastructure costs, as well as an emerging critique of urban sprawl. Calgary's city council has embraced intensification and a city-centric pattern of regional growth over the objections of developers and rural municipalities.

Edmonton is the outlier among the four cities. Its efficiency-oriented expansion policy regime appears to be intact. Civic agitation for regime change, if it exists, may be blocked by the region's polycentric governance structure - the City of Edmonton cannot impose a policy change on its neighbours, and it may not be politically possible for the Capital Region Board to do so either. 
FIGURE 13: HISTORICAL COMPARISON OF URBAN DEVELOPMENT POLICY REGIMES

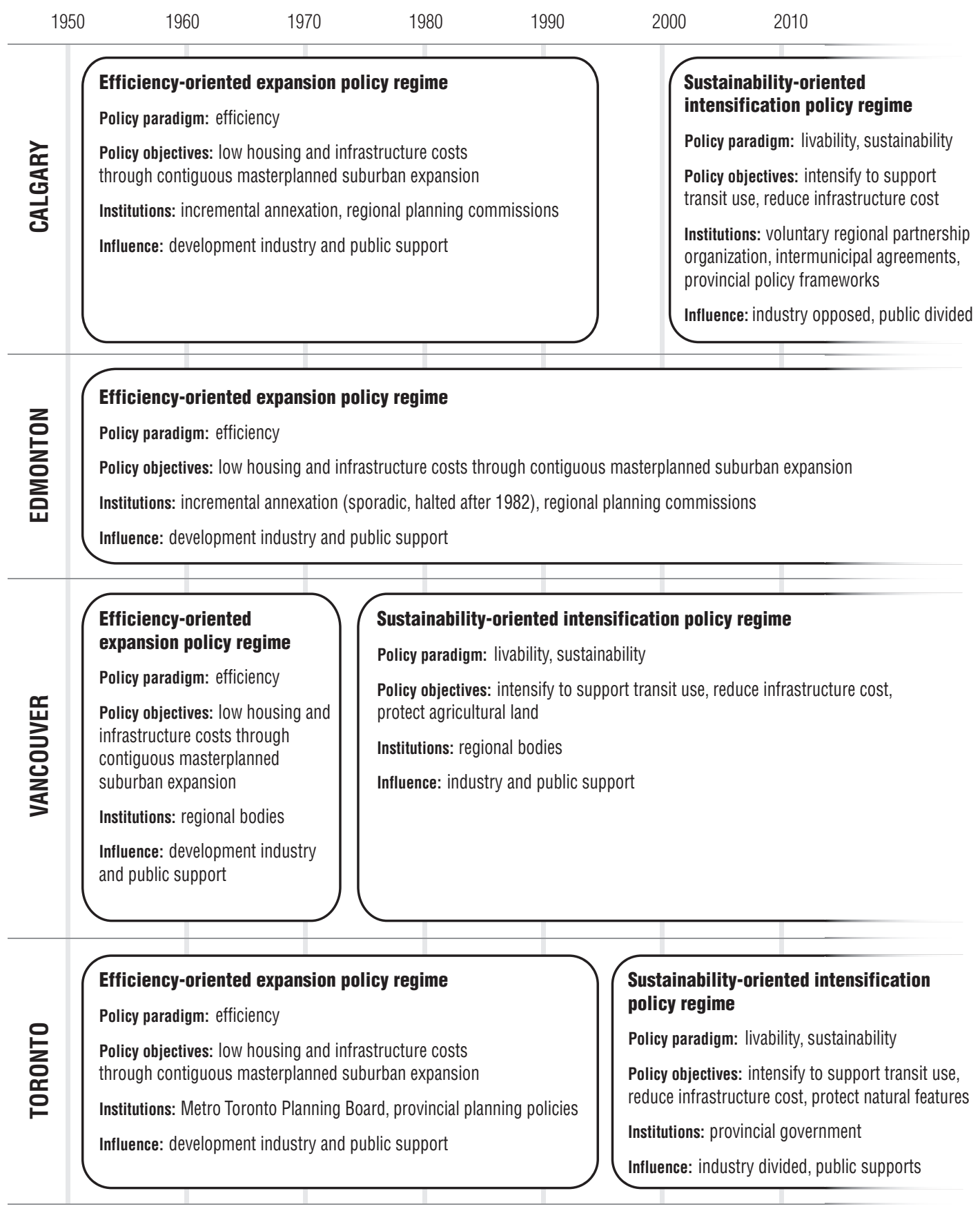




\section{Comparing Urban Development Patterns, 1991-2011}

The urban development patterns observed through the spatial analysis generally correspond with the objectives of each city's prevailing urban development policy regime. We cannot definitively say whether the policies contributed to the growth patterns or merely facilitated local market trends. It may be a bit of both; sometimes policymakers play catch-up to growth, while at other times they steer or shape the pattern of growth to achieve desired objectives. What should be clear is that at no time in the postwar period did these four cities experience so-called "unplanned sprawl." While the development of certain parts of the four regions may have been disjointed - perhaps less so in Calgary due to the consistent application of the UniCity principle - the parts themselves were carefully planned and subject to strict controls regarding the provision of infrastructure and services.

FIGURE 14: HOUSING INTENSIFICATION RATES, 1991-2011

1991-2001

\section{INTENSIFICATION}

EXPANSION

2001- 2011

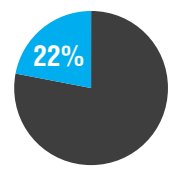

Calgary

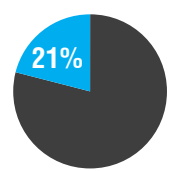

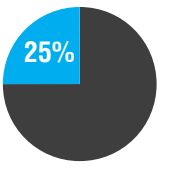

Edmonton

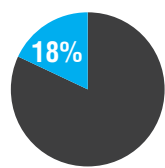

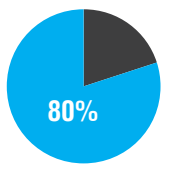

Vancouver

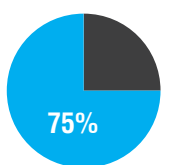

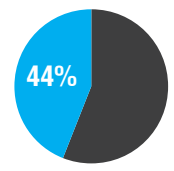

Toronto

$49 \%$

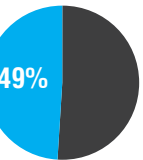

FIGURE 15: POPULATION, DWELLING UNITS AND URBAN LAND AREA, 1991-2011

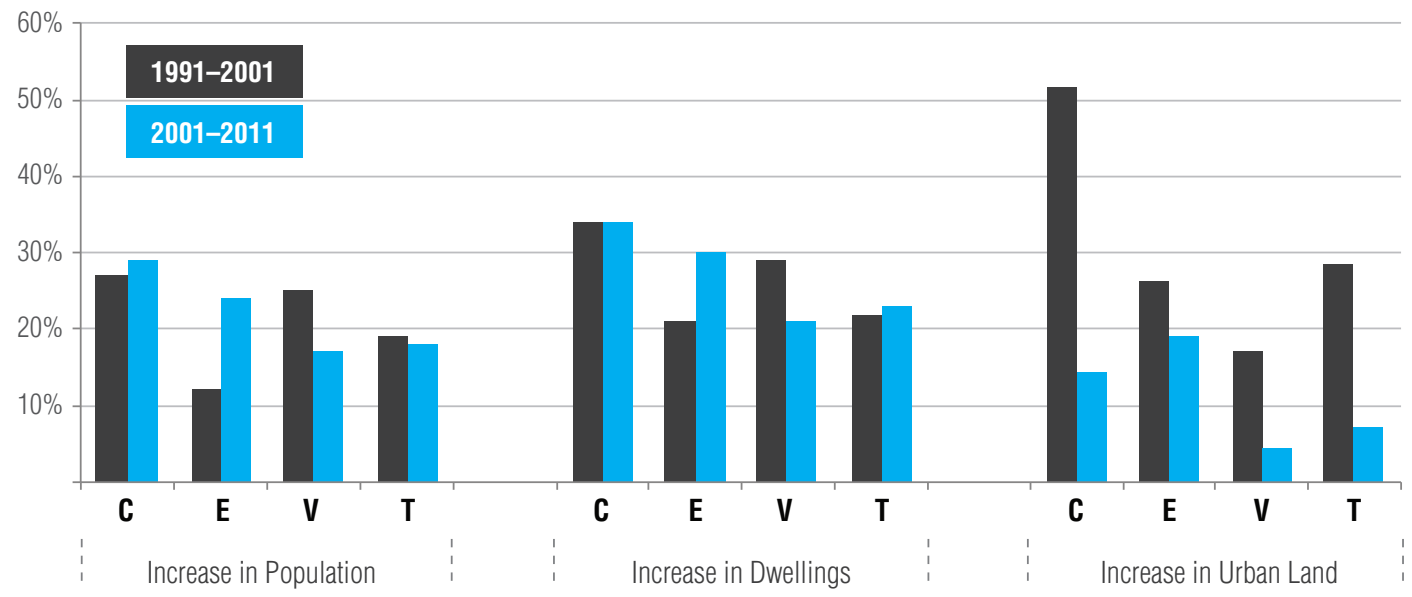




\section{HOUSING INTENSIFICATION RATES VARY CONSIDERABLY FROM CITY TO CITY}

Comparing the four cities' urban development patterns in the 1990s and 2000s reveals trends that may have long-term implications for planning policy. There is considerable variation in the distribution of growth between intensification and expansion. The proportion of the Calgary region's dwellings added within the existing built-up urban area - the intensification rate has remained consistent at about 22 per cent in each decade. Although Edmonton has a similarly low intensification rate, Toronto is moving towards a 50/50 split, while Vancouver continues to show a relatively high intensification rate. During the two decades, more than 75 per cent of all new dwellings in the Vancouver region were constructed within the existing built-up urban area (see Figure 14).

Housing intensification rates are not increasing uniformly in the four cities. While Calgary's held steady, Edmonton's decreased by a third. This finding may reflect the more fragmented organization of local and regional government institutions and relatively non-prescriptive planning policy environment in the Edmonton region. Meanwhile, Toronto's rate increased, which is consistent with the increasing policy emphasis in the region on intensification. Vancouver's rate decreased marginally, perhaps reflecting a growing scarcity of easy development opportunities within the built-up area. ${ }^{33}$ Without conducting a closer analysis, we cannot evaluate how intensification opportunities may be related to the available supply of developable sites. In both Toronto and Vancouver, much intensification has been accommodated through the redevelopment of large-scale brownfield and greyfield sites, which tend to be more abundant in older cities. Calgary and Edmonton may be at a disadvantage in this respect simply because they are younger cities.

\section{RURAL LAND CONSUMPTION IS BECOMING MORE EFFICIENT AND DENSITIES ARE INCREASING}

Each region added tens, if not hundreds of thousands of people and dwellings in each decade (see Figure 15). Calgary is the fastest growing of the four cities. Its population increased by 27 per cent between 1991 and 2001 and by a further 29 per cent between 2001 and 2011. Its housing stock grew by 34 per cent in each decade. Despite this rapid growth, the amount of land urbanized in the 2000s was considerably lower than that urbanized in the 1990s. In Calgary, the "urban footprint" increased by half in 1991-2001, but by only 14 per cent in 2001-2011. A similar decline is found in other cities, although the magnitude is smallest in Edmonton. More efficient use of suburban land, coupled with intensification of the built-up urban area, led population and housing densities to increase in all four cities in the 2000s after declining in the 1990s in all but Vancouver.

\footnotetext{
33 Note that the 1991-2001 calculation did not include the Fraser Valley Regional District, which in 2001-11 accommodated most new dwellings through expansion rather than intensification.
} 


\section{HOUSING INTENSIFICATION DOES NOT NECESSARILY GENERATE POPULATION GROWTH}

In each city, housing growth increased faster than population because of long-term demographic trends that have reduced the average size of households, including longer lifespans, delayed family formation, divorce, family planning and so on. As a result, all four cities face the depopulation of established urban areas, especially early postwar inner-ring suburbs. This is not the catastrophic disinvestment seen in the centres of many American cities. Rather, this process coexists with gentrification and reinvestment. Still, a minimum level of housing intensification is required to maintain current population levels. Millions, or even billions, of dollars of public and private capital are expended on residential infill and redevelopment projects and associated infrastructure, and yet the population that will use and pay for the infrastructure may be no greater than it was before. As a result, to borrow a phrase from Through the Looking-Glass, Lewis Carroll's sequel to Alice's Adventures in Wonderland, cities have been "running hard to keep in the same place" since the 1960s, producing ever more housing to accommodate the same population. Housing intensification without population gain, which is occurring in Calgary and Edmonton, may undermine the fiscal viability of existing and future urban services and public transit systems.

\section{Lessons for the Alberta Cities}

\section{ADAPTING TO REGIONAL POLYCENTRICITY REQUIRES MAJOR INFRASTRUCTURE INVESTMENT}

Urban development is not only about plans and land use regulation. It is also about infrastructure and how to pay for it. Toronto and Vancouver have long faced costs associated with inadequate transportation infrastructure, particularly since their polycentric urban structure poses the more difficult challenge of how best to enable commuting not simply from periphery to centre, but throughout the region. Both cities have ambitious rapid transit expansion plans, but neither has been able to resolve the politically contentious dilemma of how to fund them.

Edmonton's regional debates have revolved around its emerging polycentricity - as its downtown has declined, employment has shifted to peripheral locations, including the airport, "refinery row" and new industrial zones on the region's northeast fringe. To the extent that Edmonton suffers from traffic congestion in peak hours, it will not be remedied by radially connecting the downtown to residential suburbs. Targeted intensification may, however, bring some residents closer to their jobs and shift some automobile commuters to transit.

As it expands, Calgary is becoming a polycentric region, and may now be experiencing the limit to any efficiencies accruing to a monocentric, downtown-focused concentration of employment. The extent of the urbanized area is now so large, and commuting from satellite towns sufficiently common, that commuting times to the core have become onerous. Continued outward urban expansion in the absence of major new investments in transportation systems will only increase congestion. The city, therefore, is planning a significant expansion of the CTrain system and the completion of its circumferential highway. Whether these measures will be sufficient to solve the problem, however, remains to be seen. (It is worth noting that Toronto built its first subway, and Vancouver built the first SkyTrain line, when both regions reached Calgary's present size.) 


\section{EXTERNALLY IMPOSED LIMITS MAKE PURSUING INTENSIFICATION EASIER}

Imposing a hard limit on urban expansion in the Lower Mainland and forcing municipalities and the development industry to figure out how to make intensification work, the Agricultural Land Reserve was a crucial intervention in Vancouver. To a lesser extent, the Greenbelt may be having a similar effect in Toronto. Sitting as they do at the edge of Canada's vast agricultural heartland, Calgary and Edmonton have had little incentive to contain or restrict urban expansion to protect rural land for its own sake. As Calgary lacks an external impetus to intensify, it must make a deliberate policy choice to redirect growth to the built-up urban area. The political costs of reorienting urban development rules, practices and expectations are high; it remains to be seen whether the attempt to establish a new policy regime will become entrenched or, due to resistance from influential actors, collapse.

\section{INTENSIFICATION POLICY MUST RECOGNIZE THE DRIVERS OF HOUSING DEMAND}

As a late adopter of a pro-intensification planning approach, Calgary may have much to learn from Vancouver and Toronto. The wording of its planning policies suggests that Calgary's planners have been influenced by planning ideas from these places, including, for example, the use of density targets and the notion of "complete communities." The challenge now lies in implementation. Calgary's planners and developers might look to their counterparts in Vancouver and Toronto to understand the ground-level reality of financing, preparing, servicing and constructing infill and redevelopment projects on a wide scale.

As cities seek to intensify around transit stations and transit-connected nodes, they must find ways of attracting and channelling investment to create well-designed urban environments that balance residential development and employment. In both Toronto and Vancouver, but perhaps less so in Calgary and Edmonton, intensification has been fuelled by an exogenous factor: foreign real estate investment. Anecdotal evidence suggests that a substantial proportion of new dwellings in the two larger regions' core and waterfront areas are sold to non-resident owners in search of a predictable return on investment; many of these units are rented out or left unoccupied, potentially undermining long-term planning goals. ${ }^{34}$ Intensification driven by endogenous demand would better support services and infrastructure systems while addressing congestion.

Ultimately, the most important phenomenon to address is one Calgary shares with Edmonton: physical intensification without population growth. Housing intensification must increase population in absolute terms if it is to offset ongoing population loss in established areas. Toronto's example is illustrative: while about half of all new dwellings constructed in the region between 2001 and 2011 were located in the built-up urban area, these dwellings contained only 21 per cent of new residents. ${ }^{35}$ In this situation, cities may end up paying for improved infrastructure and services for users who never arrive.

\footnotetext{
34 David P. Ball, "Vancouver Foreign Investment Panel Tackles 'Safety Deposit' Condos for Wealthy, The Tyee, March 25, 2013, XX; and Terrence Belford, "Chinese Stoke Toronto's Condo Boom," Globe and Mail, November 12, 2010, XX.

35 This trend may be driven by housing demand. Almost half of all intensification (93,400 units) in Toronto was in the form of small-format dwellings - mid-to-high-rise condominium and rental apartments. At the same time, the detached housing stock declined by 34,600, partly as a result of redevelopment activity. Larger households may look to the suburbs for suitable affordable homes.
} 


\section{ESTABLISHING A NEW URBAN DEVELOPMENT POLICY REGIME IN CALGARY WILL NOT BE EASY}

How well positioned is Calgary as it seeks to reorient its urban development policy regime? In a sense, Vancouver represents the future that recent planning efforts in Calgary and Toronto are intended to achieve, one that features carefully designed densification. Is it possible for Calgary to become more like Vancouver?

The functioning of governing institutions - the incentives they generate and the operating practices and organizational cultures embedded within them - is central to the reproduction of Vancouver's urban development policy regime. The Lower Mainland incrementally developed its system of regional planning through collaborative governance over the course of a century, overcoming many disagreements along the way. It took half a century before the voluntary water, sewer and planning boards were transformed into the compulsory Greater Vancouver Regional District, and a further 25 years before today's consensus-based regional planning system was institutionalized. A shared belief in urban containment and intensification is now deeply embedded in local political discourse and in the practices of planning professionals and the developer-builder industry.

Regional planning in Calgary is increasingly a multi-level process in which the provincial government, the Calgary Regional Partnership, the city and its neighbours negotiate objectives. With its new Land-Use Framework and its encouragement of collaborative regional planning, Alberta has hybridized British Columbia-style intermunicipal collaboration with Ontario's province-led policy hierarchy. The partial boycott of the Calgary Regional Partnership by rural municipalities, however, indicates that incentives for cooperation are lacking. Indeed, it appears that Calgary's control over water supply is the only glue holding the partnership together. Calgary is trying to telescope the same trust-building process into a much shorter period of time, and on shallower foundations. More so than in the past, the City of Calgary risks shifting growth to locations beyond its borders if it acts unilaterally. The pursuit of Calgary's adopted municipal planning goals requires regional cooperation.

Toronto's example offers no easy lessons either. Since the 1970s, regional coordination and policymaking have relied entirely on the willingness of the provincial government to set coherent planning goals, impose them on municipalities, and monitor and enforce compliance. When the province has failed to do so, intermunicipal coordination and policy coherence have disintegrated. It remains to be seen how prescriptive the Alberta Land Stewardship Act plans will be, and how they will relate to regional and municipal plans in the province's two largest cities. The Alberta government may yet do for Calgary what it did for Edmonton: compel participation in an authoritative regional planning body. For now, however, the provincial government sees no political advantage in doing so.

Today, strident opposition by a powerful and well-organized local developer-builder industry that has no incentive to depart from a highly profitable suburban development model is coupled with weakly institutionalized regional coordination and inconsistent political support on city council for the new planning direction. If this condition persists, Calgary may find it difficult to reorient its urban development policy regime from one premised on expansion and efficiency objectives to one oriented around intensification and sustainability objectives. 


\section{About the Authors}

Zack Taylor (MCIP RPP) is Assistant Professor in the Department of Human Geography and City Studies Program, University of Toronto Scarborough. His teaching and research focuses on land-use planning policymaking and evaluation, planning history, metropolitan governance, institutional theory and local public finance. He previously served as research coordinator for the Neptis Foundation.

Marcy Burchfield (MSc) is the Executive Director of the Neptis Foundation, a Canadian independent and charitable foundation that funds and conducts nonpartisan research on Canadian urban regions. For the last 15 years, she has applied her graduate studies in spatial analysis and remote sensing to developing innovative techniques for studying growth and change in Canadian cities.

Anna Kramer (PhD) completed her doctoral studies at the University of Waterloo with a dissertation on housing affordability in relation to public transit in North American cities. As a researcher at Neptis, she analyzed spatial patterns of residential growth in four Canadian cities to update the original Growing Cities research. She currently works at Metrolinx. 


\title{
ABOUT THE SCHOOL OF PUBLIC POLICY
}

The School of Public Policy will become the flagship school of its kind in Canada by providing a practical, global and focused perspective on public policy analysis and practice in areas of energy and environmental policy, international policy and economic and social policy that is unique in Canada.

The mission of The School of Public Policy is to strengthen Canada's public service, institutions and economic performance for the betterment of our families, communities and country. We do this by:

- Building capacity in Government through the formal training of public servants in degree and non-degree programs, giving the people charged with making public policy work for Canada the hands-on expertise to represent our vital interests both here and abroad;

- Improving Public Policy Discourse outside Government through executive and strategic assessment programs, building a stronger understanding of what makes public policy work for those outside of the public sector and helps everyday Canadians make informed decisions on the politics that will shape their futures;

- Providing a Global Perspective on Public Policy Research through international collaborations, education, and community outreach programs, bringing global best practices to bear on Canadian public policy, resulting in decisions that benefit all people for the long term, not a few people for the short term.

\author{
The School of Public Policy \\ University of Calgary, Downtown Campus \\ 906 8th Avenue S.W., 5th Floor \\ Calgary, Alberta T2P $1 \mathrm{H} 9$ \\ Phone: 4032107100
}

\section{DISTRIBUTION}

Our publications are available online at www.policyschool.ca.

\section{DISCLAIMER}

The opinions expressed in these publications are the authors' alone and therefore do not necessarily reflect the opinions of the supporters, staff, or boards of The School of Public Policy.

\section{COPYRIGHT}

Copyright (C) 2014 by The School of Public Policy.

All rights reserved. No part of this publication may be reproduced in any manner whatsoever without written permission except in the case of brief passages quoted in critical articles and reviews.

\section{ISSN}

1919-112x SPP Research Papers (Print)

1919-1138 SPP Research Papers (Online)

\section{DATE OF ISSUE}

May 2014

\section{MEDIA INQUIRIES AND INFORMATION}

For media inquiries, please contact Morten Paulsen at 403-453-0062.

Our web site, www.policyschool.ca, contains more information about The School's events, publications, and staff.

\section{DEVELOPMENT}

For information about contributing to The School of Public Policy, please contact Courtney Murphy by telephone at 403-210-7201 or by e-mail at cdmurphy@ucalgary.ca. 


\section{RECENT PUBLICATIONS BY THE SCHOOL OF PUBLIC POLICY}

THE MIDDLE POWER AND THE MIDDLE KINGDOM: SECURING CANADA'S PLACE IN THE NEW CHINA-U.S. ECONOMIC AND STRATEGIC WORLD ORDER $\mathrm{http}: / /$ policyschool.ucalgary.ca/?q=content/middle-power-and-middle-kingdom-securing-canadas-place-new-china-us-economic-and-strategic-w Wendy Dobson | April 2014

SAFETY IN NUMBERS: EVALUATING CANADIAN RAIL SAFETY DATA

http://policyschool.ucalgary.ca/?q=content/safety-numbers-evaluating-canadian-rail-safety-data

Jennifer Winter | April 2014

CHINA'S STATE-OWNED ENTERPRISES AND CANADA'S FDI POLICY

http://policyschool.ucalgary.ca/?q=content/chinas-state-owned-enterprises-and-canadas-fdi-policy

Wendy Dobson | March 2014

THE TAMING OF THE SKEW: FACTS ON CANADA'S ENERGY TRADE

http://policyschool.ucalgary.ca/?q=content/taming-skew-facts-canadas-energy-trade

Trevor Tombe | March 2014

CANADA-KOREA FREE TRADE: A WATERSHED IN ECONOMIC INTEGRATION WITH ASIA

http://policyschool.ucalgary.ca/?q=content/canada-korea-free-trade-watershed-economic-integration-asia

Eugene Beaulieu | March 2014

KEEPING THE GENIE IN THE BOTILE: GRADING THE REGULATION OF CANADIAN FINANCIAL INSTITUTIONS

http://policyschool.ucalgary.ca/?q=content/keeping-genie-bottle-grading-regulation-canadian-financial-institutions

John Chant | March 2014

SIMULATED REPLACEMENT RATES FOR CPP REFORM OPTIONS

http://policyschool.ucalgary.ca/?q=content/simulated-replacement-rates-cpp-reform-options

Kevin Milligan and Tammy Schirle | March 2014

ABORIGINAL-CANADIANS AND ENERGY LITERACY: A SURVEY OF OPINIONS AND THOUGHTS ON ENERGY

http://policyschool.ucalgary.ca/?q=content/aboriginal-canadians-and-energy-literacy-survey-opinions-and-thoughts-energy

Michal C. Moore, André Turcotte and Jennifer Winter | February 2014

THE RISE AND FALL OF SOCIAL ASSISTANCE USE IN CANADA, 1969-2012

http://policyschool.ucalgary.ca/?q=content/rise-and-fall-social-assistance-use-canada-1969-2012

Ron Kneebone and Katherine White | February 2014

INCOME ADEQUACY AMONG CANADIAN SENIORS: HELPING SINGLES MOST

http://policyschool.ucalgary.ca/?q=content/income-adequacy-among-canadian-seniors-helping-singles-most

Philip Bazel and Jack Mintz | February 2014

ENERGY EFFICIENCY: FINDING LEADERSHIP OPPORTUNITIES

http://policyschool.ucalgary.ca/?q=content/energy-efficiency-finding-leadership-opportunities

William D. Rosehart and Hamidreza Zareipour | February 2014

SHOULD CANADA WORRY ABOUT A RESOURCE CURSE?

http://policyschool.ucalgary.ca/?q=content/should-canada-worry-about-resource-curse

Alan Gelb | January 2014

PRIORITIZING DEFENCE INDUSTRY CAPABILITIES: LESSONS FOR CANADA FROM AUSTRALIA

$\mathrm{http}: / /$ policyschool.ucalgary.ca/?q=content/prioritizing-defence-industry-capabilities-lessons-canada-australia

Craig Stone | January 2014 